\title{
A new fossil species of the genus Bibio, with an update on bibionid flies from Baltic and Rovno amber (Diptera, Bibionidae)
}

\author{
John Skartveit ${ }^{1}$ \\ 1 NLA University College Bergen, P.O. Box 74 Sandviken, N-5812 Bergen, Norway \\ http://zoobank.org/2AD03B67-2D3B-4B03-A373-59854A506F3E \\ Corresponding author: John Skartveit (John.Skartveit@NLA.no)
}

Academic editor: S. Wedmann • Received 10 November 2020 • Accepted 14 January 2021 • Published 27 January 2021

\begin{abstract}
Species of Bibionidae from Baltic amber are reevaluated based on newly discovered material, and a key to the species is given. Bibio succineus sp. nov. is described based on one male specimen, this is the first Bibio named from Baltic amber. The males of Hesperinus electrus Skartveit, 2009 and Penthetria montanaregis Skartveit, 2009 are redescribed. A single, autoclave treated specimen of Penthetria sp. is described but not formally named. Plecia tenuicornis Skartveit, 2009 is found to be a synonym of Plecia hoffeinsorum Skartveit, 2009, this species is recorded for the first time from Rovno amber, and both sexes of the species redescribed. Additional specimens of Plecia clavifemur Skartveit, 2009 and Dilophus crassicornis Skartveit, 2009 are described. Two female specimens probably belonging to the species discussed as Dilophus sp. by Skartveit (2009) are described, but not formally named.
\end{abstract}

\section{Key Words}

Dilophus, Hesperinus, Penthetria, Plecia, Eocene

\section{Introduction}

Bibionid flies are a very abundant group in European Tertiary insect fossil deposits (e.g., Skartveit and Nel 2017), where they frequently make up a large percentage of the total insect specimens. On the other hand, bibionid specimens are relatively scarce among amber fossils, though a number of species have been described from European amber fossils (Gee et al. 2001; Skartveit 2009). Outside Europe, bibionid flies are known from Cretaceous Canadian (Peterson 1975), Miocene Dominican (Waller et al. 2000; Skartveit and Bechly 2013) and Chiapas (Hardy 1971) amber.

Rovno amber comes from mines in Rivne Oblast, Ukraine (Perkovsky et al. 2010). The deposits have been dated to the Lower Oligocene, suggesting a younger age than Baltic amber (Perkovsky et al. 2010), though more recently it has been redated to the late Eocene (Perkovsky and Makarkin 2019). While the fauna in Rovno amber is rather similar to the one in Baltic amber, suggesting they are of the same age and origin (e.g., Dlussky and Rasnitsyn 2009; Szwedo and Sontag 2013), some differences have been noted between the two palaeofaunas (Perkovsky et al. 2007), with about 100 taxa found in Rovno amber not recorded from Baltic amber (Perkovsky et al. 2010). Rovno and Baltic amber are very similar in chemical composition; however, analyses of stable carbon and hydrogen isotopes in Rovno, Bitterfeld and Baltic amber suggest that Rovno amber is of similar age to Baltic amber, but originated in a more southerly location (Mänd et al. 2018). Bibionid flies have not previously been recorded from Rovno amber.

I (Skartveit 2009) reviewed a reasonably large material of bibionids from Baltic amber. Subsequently, some additional specimens have surfaced which can shed some light on the Baltic amber bibionid fauna; they are described here. 


\section{Methods}

The present paper is based on 16 specimens of Bibionidae in Baltic amber. The specimens were in cut and polished pieces of amber acquired through commercial dealers, unfortunately without any information on where they were collected except that they were from Baltic (or Rovno) amber. The dealers provided digital images of the specimens, I carried out further studies of the specimens under stereo microscopes (Olympus SZ61, WildM3Z), photographs were taken with digital cameras (Nikon 4500, Olympus E3), I collected measurements using measuring oculars. I made line drawings based on digital images of the specimens.

Wing vein nomenclature mainly follows Merz and Haenni (2000), with the modification that the section of $R$ between crossvein $R-M$ and $R_{2+3}$ is referred to as $R_{2-5}$.
The segment of $\mathrm{M}$ basal to R-M is referred to as "basal M", the segment between R-M and furcation as "distal M". The naming of the veins is shown in Fig. 12.

\section{Repositories, Institutional acronyms or Institutional abbreviations}

CCHH Collection of Christel and Hans-Werner Hoffeins, Hamburg, Germany, to be deposited in SDEI.

JS Author's collection, to be deposited in SDEI.

MHNN Museum d'histoire naturelle, Neuchâtel, Switzerland.

SDEI Senckenberg Deutsches Entomologisches Institut, Müncheberg, Germany.

\section{Results}

\section{Key to the species of Bibionidae known from Baltic amber}

Plecia borussica Meunier, 1907 is not included since I have not been able to locate any material of it, and Plecia sp. 3 of Skartveit (2009) is not included since the antennae were impossible to see in the specimen at hand. The former species should be recognisable by the gonostyli being obviously expanded apically, the latter by the epandrium having a sharp spine in the middle.

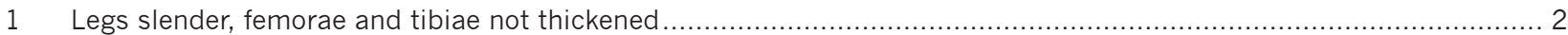

- $\quad$ Legs thickened, at least fore femorae clearly expanded (Bibioninae) ............................................................ 12

2 Antenna longer than head (Fig. 13). (genus Hesperinus) ….................................................................... 3

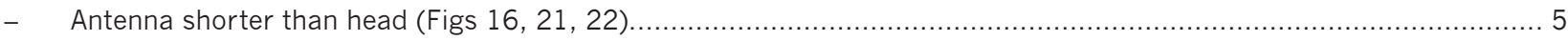

3 Antennal flagellum 10-segmented. Wing hyaline with unpigmented veins and invisible pterostigma (female only known) ........................................................................................Hesperinus hyalopterus Skartveit, 2009

- $\quad$ Antennal flagellum 7-8-segmented. Wing with veins brownish, pterostigma more or less visible (males only known).... 4

4 Head strongly dichoptic, complex eyes widely separated dorsomedially. Gonostylus curved and sharply pointed (Fig. 1)...... Hesperinus electrus Skartveit, 2009

- Head weakly dichoptic, complex eyes nearly meeting dorsomedially. Gonostylus nearly straight and blunt.....

5 Vein $\mathrm{R}_{2.5}$ unforked, no vein $\mathrm{R}_{2+3}$ (possibly a teratology, but known from two specimens). Hesperinus macroculatus Skartveit, 2009 Vein $R_{2.5}$ forked, with a clear vein $R_{2+3}$ (Figs 15, 18-20).

Penthetria integroneura Skartveit, 2009

6 Wing with $\mathrm{R}_{2+3}$ straight, forming a sharp angle with $\mathrm{R}_{4+5}$ (Figs 15, 18). Male terminalia with strong, blunt gonostyli and bilobate epandrium (Fig. 17)........

- Wing with $\mathrm{R}_{2+3}$ more or less curved, forming a less sharp angle with $\mathrm{R}_{4+5}$ (Figs 19, 20). Male terminalia not so, epandrium

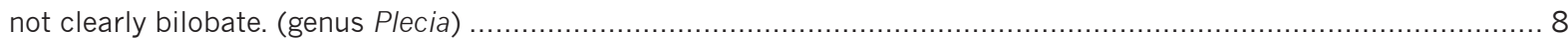

7 Vein $R_{2+3}$ originates near base of $R s$, so that the segment $R_{2.5}$ is not much more than half as long as $R_{4+5}(F i g s 2,15) \ldots$ Penthetria montanaregis Skartveit, 2009

- $\quad$ Vein $\mathrm{R}_{2+3}$ originates near middle of $\mathrm{Rs}$, so that the segment $\mathrm{R}_{2.5}$ is nearly as long as $\mathrm{R}_{4+5}$ (Figs 3,18 )....... Penthetria sp.

8 Wing with $\mathrm{R}_{4+5}$ kinked at junction with $\mathrm{R}_{2+3}$, which is short and almost vertical (Fig. 4) ....Plecia clavifemur Skartveit, 2009

- $\quad$ Wing with $\mathrm{R}_{4+5}$ not kinked at junction with $\mathrm{R}_{2+3}$, which is longer and less steep (Figs 19, 20) .............................. 9

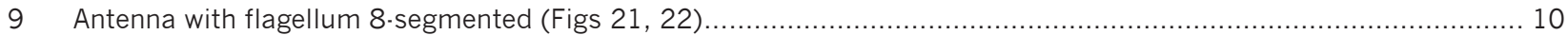

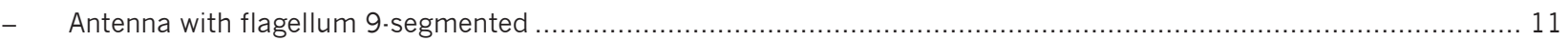

10 Wing with strong microtrichia, pterostigma dorsally densely pilose. Male: gonostylus straight, long and slender (Fig. 23). Female eye small, not strongly protruding (Fig. 22) (Figs 5-7)..............................Plecia hoffeinsorum Skartveit, 2009

- $\quad$ Wing with fine microtrichia, pterostigma not conspicuously pilose. Male unknown. Female eye large and protruding ..... Plecia prisca Meunier, 1899

11 Larger, mesonotum length about $1.6 \mathrm{~mm}$. Female only known. Plecia brunniptera Skartveit, 2009

- $\quad$ Smaller, mesonotum length about $0.8 \mathrm{~mm}$. Male only known Plecia sp. 1 Skartveit, 2009 
12 Thorax without spines on pronotum and mesonotum (Fig. 25). Anterior tibia without mesal spines and apical spine circlet (Fig. 26)

- Thorax with transverse rows of spines on pronotum and mesonotum (Fig. 29). Anterior tibia with mesal spines and apical spine circlet (Fig. 30) (genus Dilophus)

Bibio succineus sp. nov.

13 Rs does not extend to M, with a short but distinctive crossvein R.M. (Figs 8, 24)

14 Larger species, body length 4-4.5 mm. Male hind first tarsomere swollen. Male gonostylus bilobate

..Bibiodes balticus Skartveit, 2009

- Very small species, body length 2.5-3 mm. Male hind first tarsomere not swollen. Male gonostylus simple digitiform .... . Bibiodes nanus Skartveit, 2009

15 Antenna short and stout, flagellum 6-7-segmented (Fig. 29). Protibial mesal spines long and erect (Fig. 30) (Fig. 9).... Dilophus crassicornis Skartveit, 2009

- Antenna longer, more slender, flagellum with at least 9 segments (Fig. 33). Protibial mesal spines not long and erect (Fig. 34)

16 Antennal flagellum 9-10-segmented, not very slender (Fig. 33). Fore tibia with $2+2$ mesal spines (Fig. 34) (Figs 10, 11)

..Dilophus sp.

- $\quad$ Antennal flagellum 12-segmented, slender. Fore tibial spines otherwise ..................................................... 17

17 Fore tibia with 2+3 strong, mesal spines. Antenna longer, nearly as long as head ..... Dilophus succineus Skartveit, 2009

- $\quad$ Fore tibia with 1+2 rather small, mesal spines. Antenna shorter, considerably shorter than head.....

. Dilophus palaeofebrilis Skartveit, 2009

\section{Taxonomy}

\section{Hesperinus electrus Skartveit, 2009: 5-7}

Figs 1, 12-14

Note. The species was described based on a single, male specimen (Skartveit 2009). One additional male specimen has turned up which shows details in wing venation and terminalia better than the type.
Holotype (male) SDEI Dip-00832 - CCHH \#1093-1. Additional material (male) CCHH \# 1789-1

Updated description of the species including type specimen (some measurements from the holotype corrected): Total length $4.35-4.40 \mathrm{~mm}(\mathrm{~N}=2)$. Colour dark brownish, body semi-matt, covered with short, coarse, dark hairs.

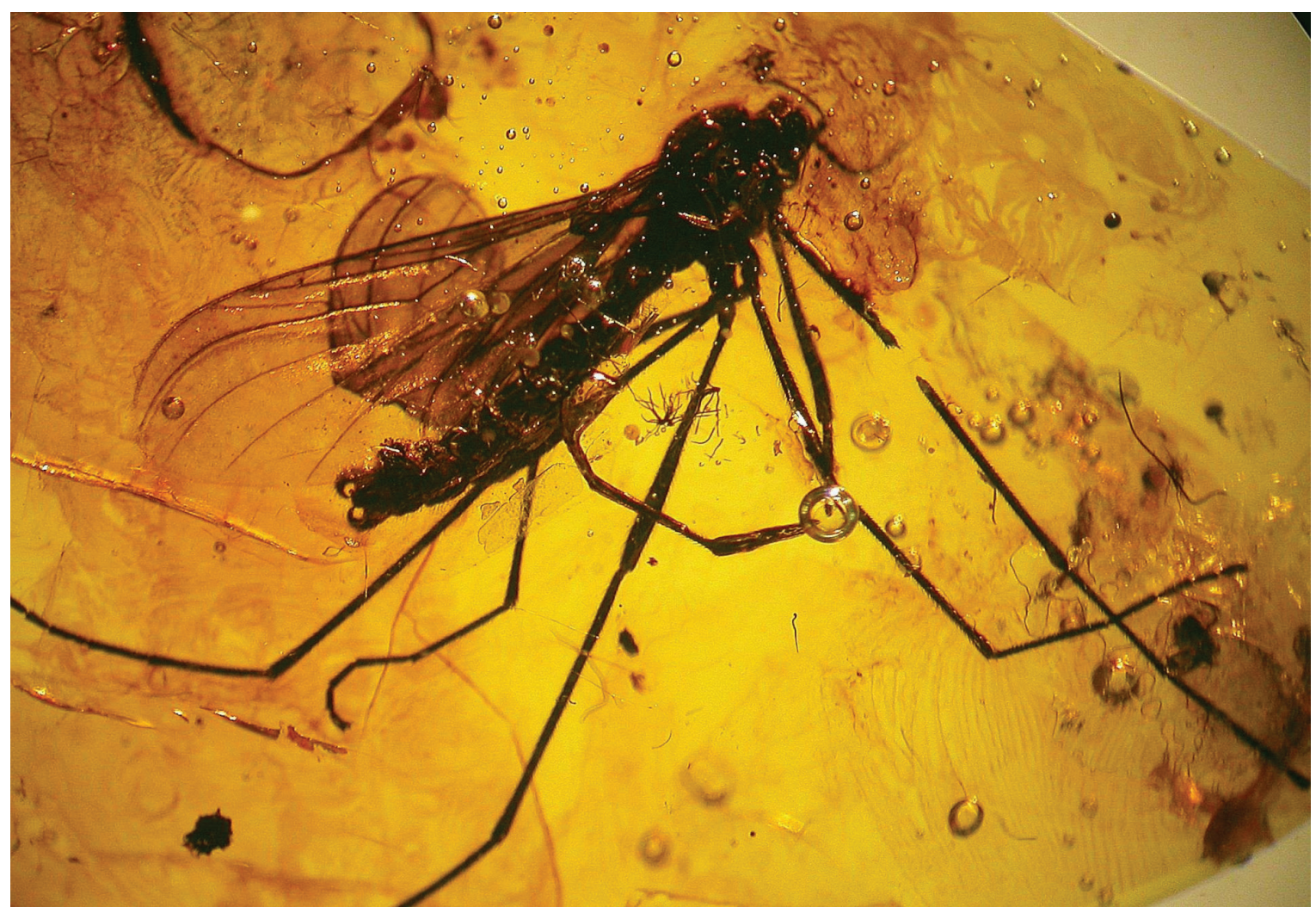

Figure 1. Hesperinus electrus, male. CCHH \# 1789.1. Photo: Christel and Hans-Werner Hoffeins. 


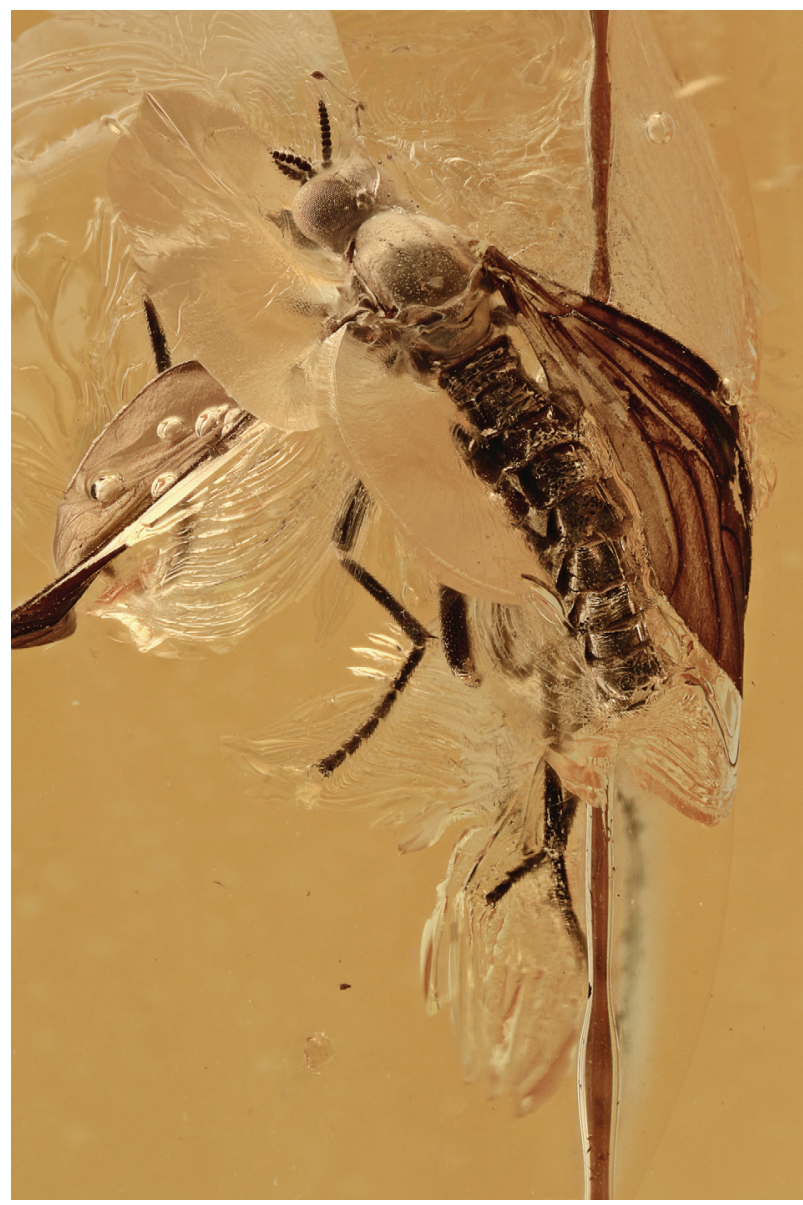

Figure 2. Penthetria montanaregis, male. JS-Baltic-001. Photo: Marius Veta.
Head (Fig. 13): Length 0.47-0.52 mm $(\mathrm{N}=2)$. Clearly dichoptic, complex eyes separated in frons by about the width of ocellar tubercle. Ocellar tubercle medium-sized, fairly prominent. Complex eye somewhat reniform, concave posteriorly, without apparent intraocular setae. Occiput with rather dense, short, dark pile. Antenna slender, about one and a half times as long as head, flagellum $0.78 \mathrm{~mm}$ long, $0.06 \mathrm{~mm}$ wide $(\mathrm{N}=2)$, eight-segmented, all flagellomeres clearly longer than wide, with dark setae about as long as the width of the flagellomeres. Pedicel conical, pedicel and first flagellomere wider than the rest of flagellum. Palp brown, relatively long, last segment cylindrical. Mouthparts, apart from palp, not conspicuously developed.

Thorax: Length 0.90-0.92 $\mathrm{mm}(\mathrm{N}=2)$, width $0.55 \mathrm{~mm}$ $(\mathrm{N}=1)$. Reddish brown with darker vittae around notaulix and anterolaterally at humerus, semi-matt, grayish pruinose, with sparse, short setae. Mesonotum with deep sulci. Pleura bare, densely grayish pruinose except for glabrous patches posteriorly on katepisternum and epimeron. Haltere brown.

Wing (Fig. 12) Length 4.18-4.35 $\mathrm{mm}(\mathrm{N}=2)$, width $1.32-1.52 \mathrm{~mm}(\mathrm{~N}=2)$, length/width $=2.75-3.30$ (wing of holotype may be slightly folded). Very slightly brownish fumose, membrane with very fine microtrichia, veins fine and brown throughout. Pterostigma not apparent. Costa with fine setulae about as long as width of vein, extends to nearly half-way between apices of $R_{4+5}$ and $M_{1}$. Humeral vein short and oblique. $\mathrm{R}_{2+3}$ rather long, oblique, basally bent. $\mathrm{R}_{4+5}$ strongly curved. R-M nearly vertical. M-veins apically very fine, hardly visible at wing edge, a

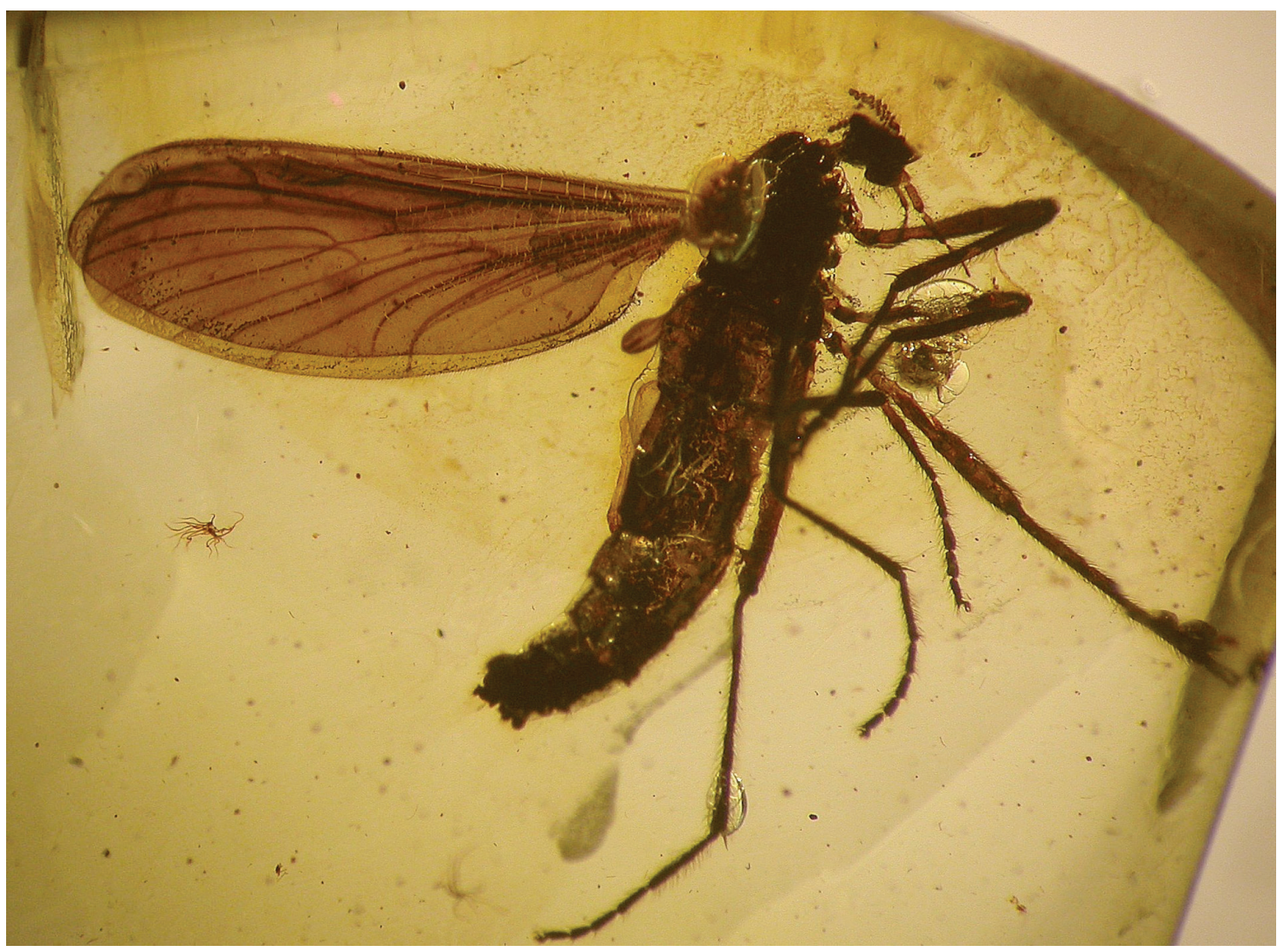

Figure 3. Penthetria sp., female. SDEI Dip-00823 - CCHH\#1789-4. Photo: Christel and Hans-Werner Hoffeins. 


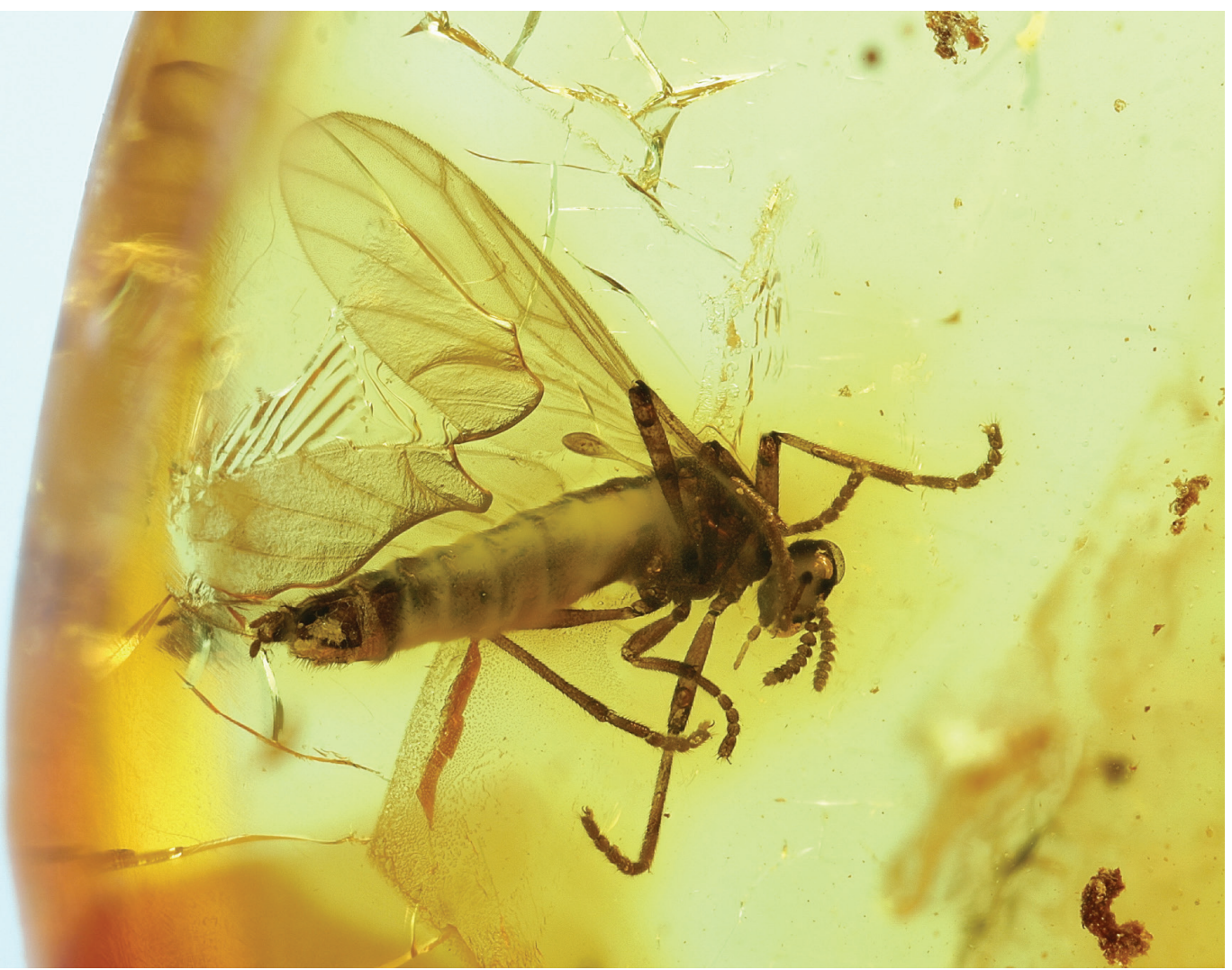

Figure 4. Plecia clavifemur, female. JS-Baltic-003. Photo: Jonas Damzen.

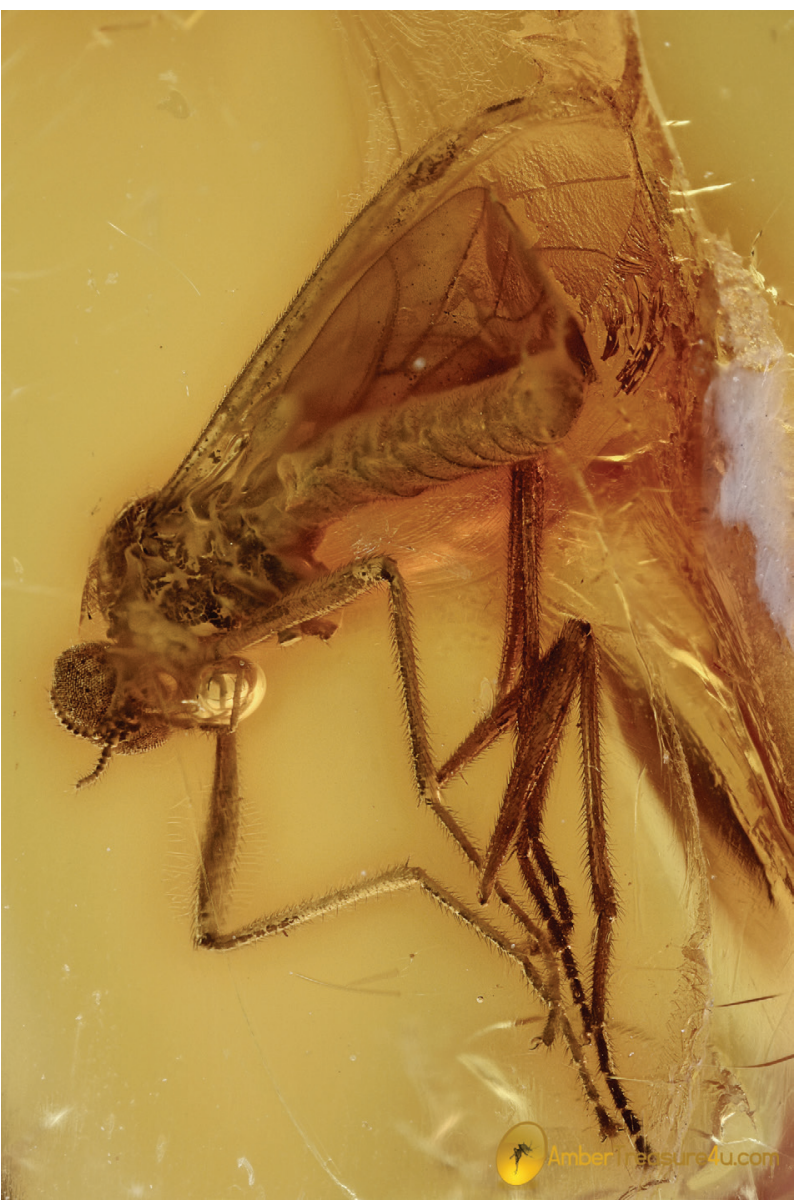

Figure 5. Plecia hoffeinsorum, male. JS-Baltic-004. Photo: Marius Veta.

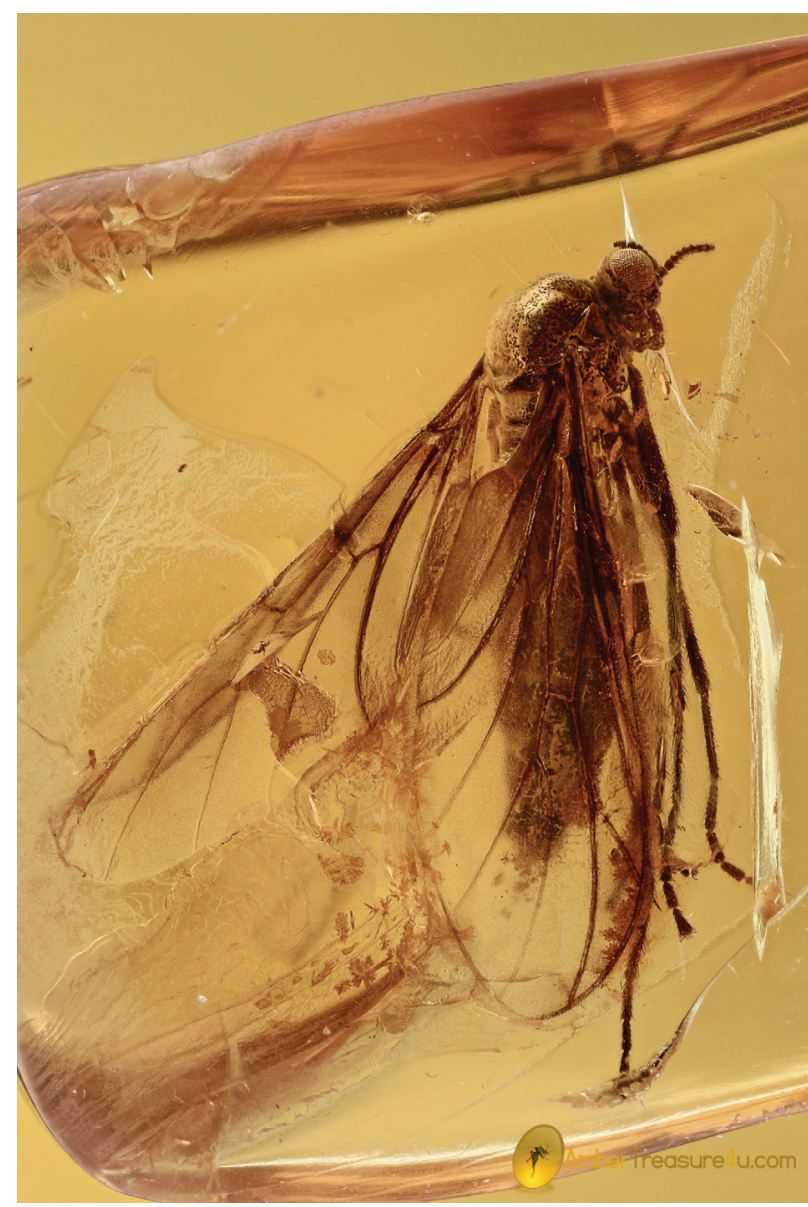

Figure 6. Plecia hoffeinsorum, female. JS-Baltic-006. Photo: Marius Veta. 


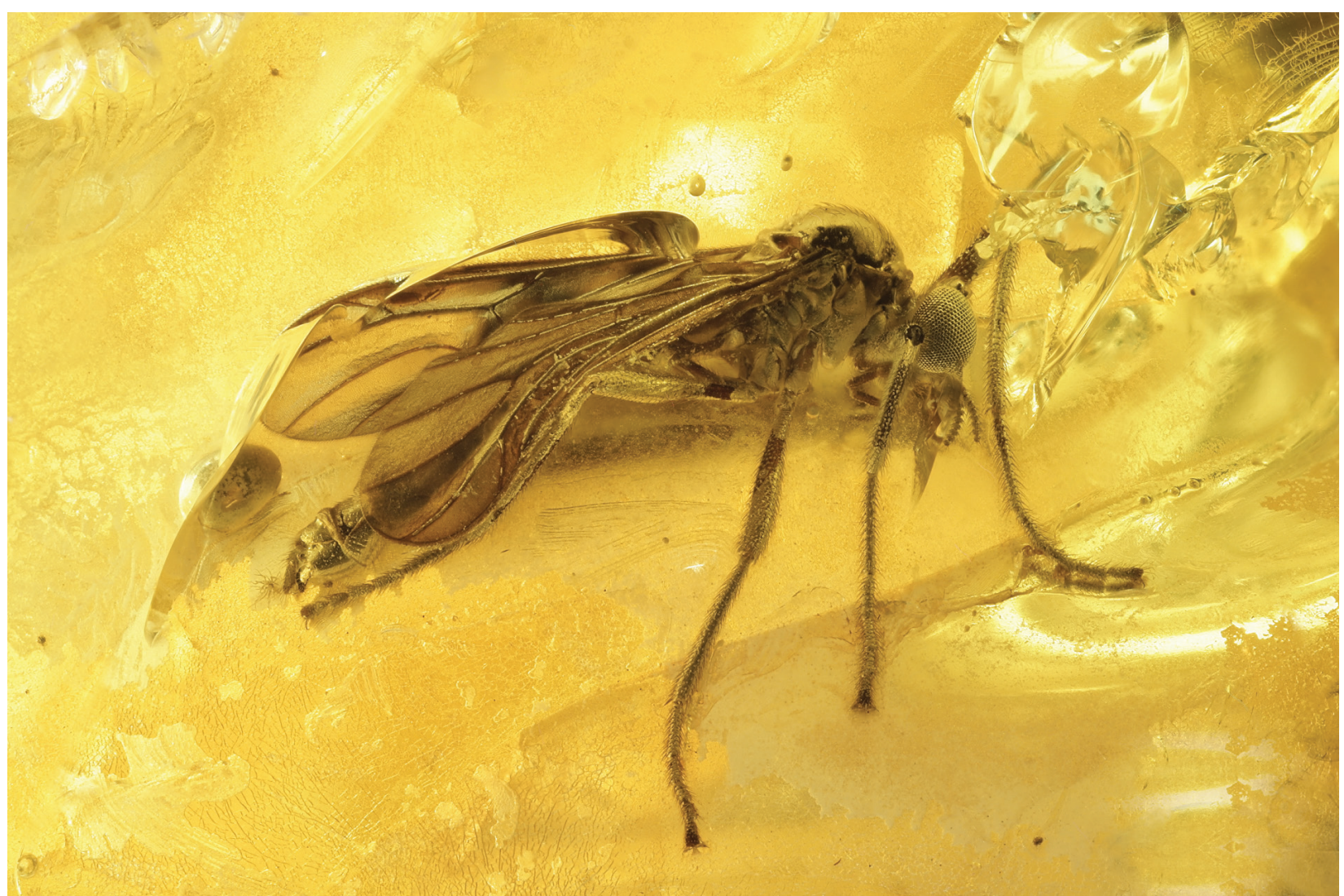

Figure 7. Plecia hoffeinsorum, male, Rovno amber. JS-Baltic-008. Photo: Jonas Damzen.

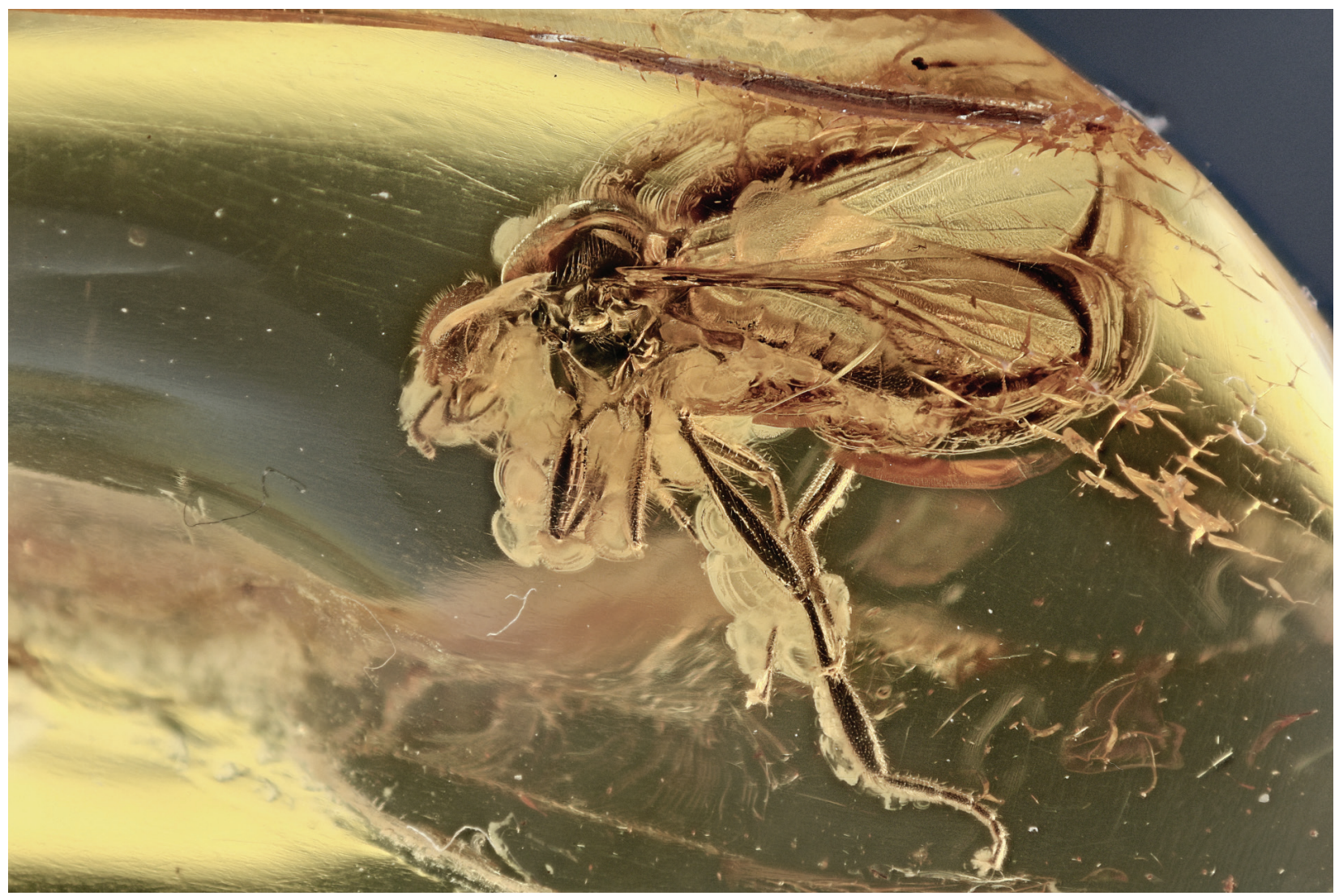

Figure 8. Bibio succineus sp. nov., holotype, male. JS-Baltic-009. Photo: Marius Veta. 


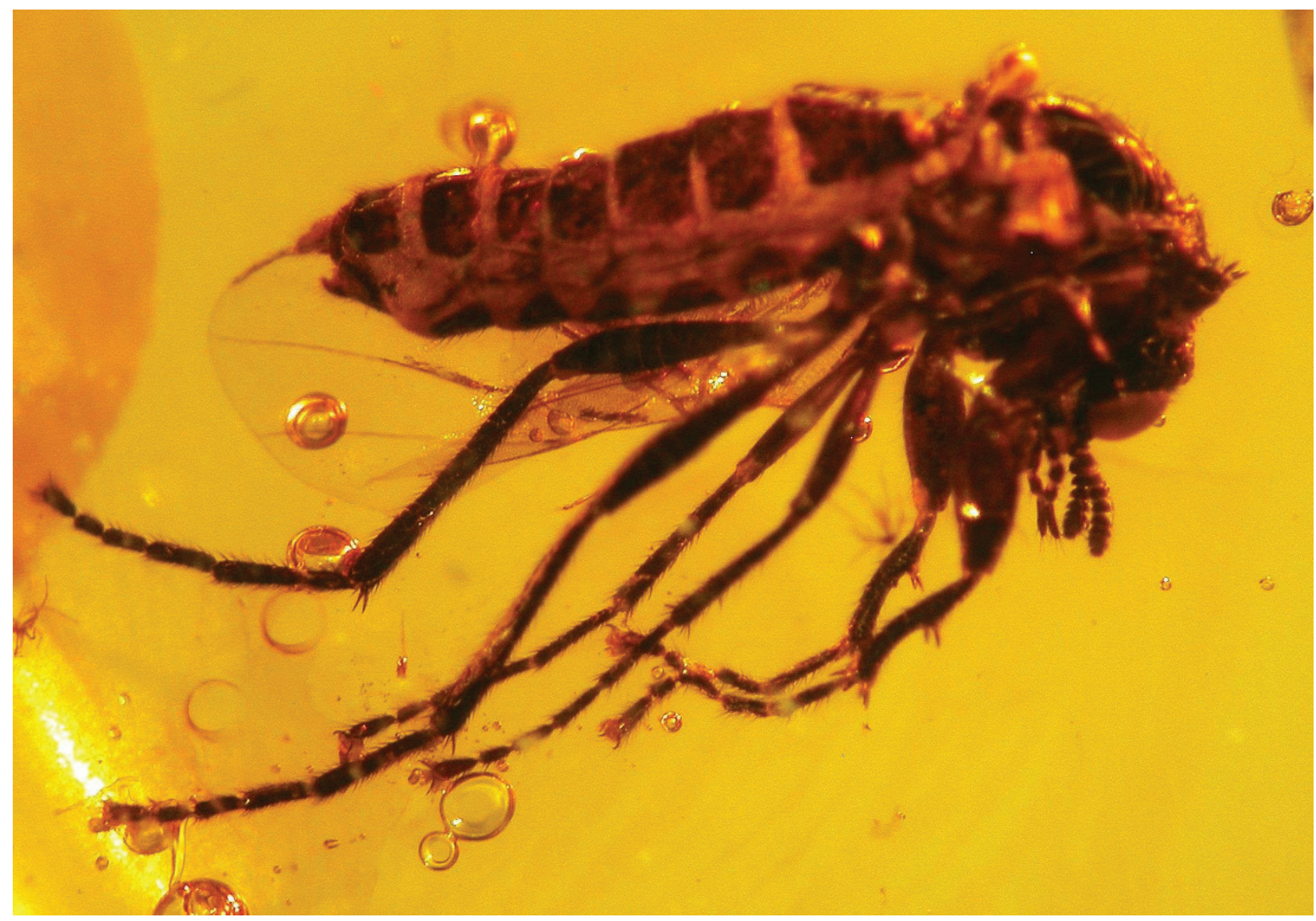

Figure 9. Dilophus crassicornis, female. CCHH \# 1789-2. Photo: Christel and Hans-Werner Hoffeins.

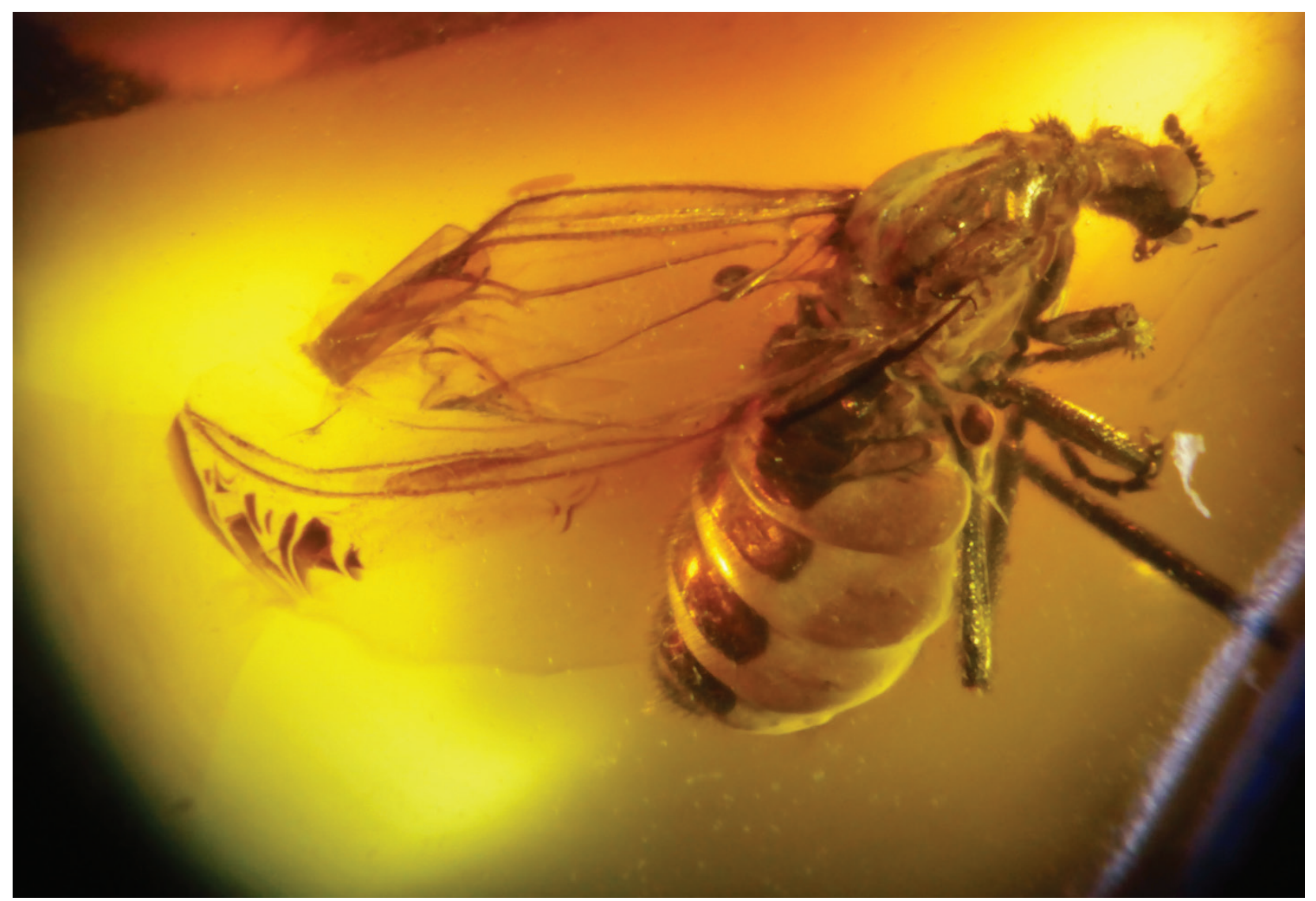

Figure 10. Dilophus sp., female. JS-Baltic-010. Photo: John Skartveit. 


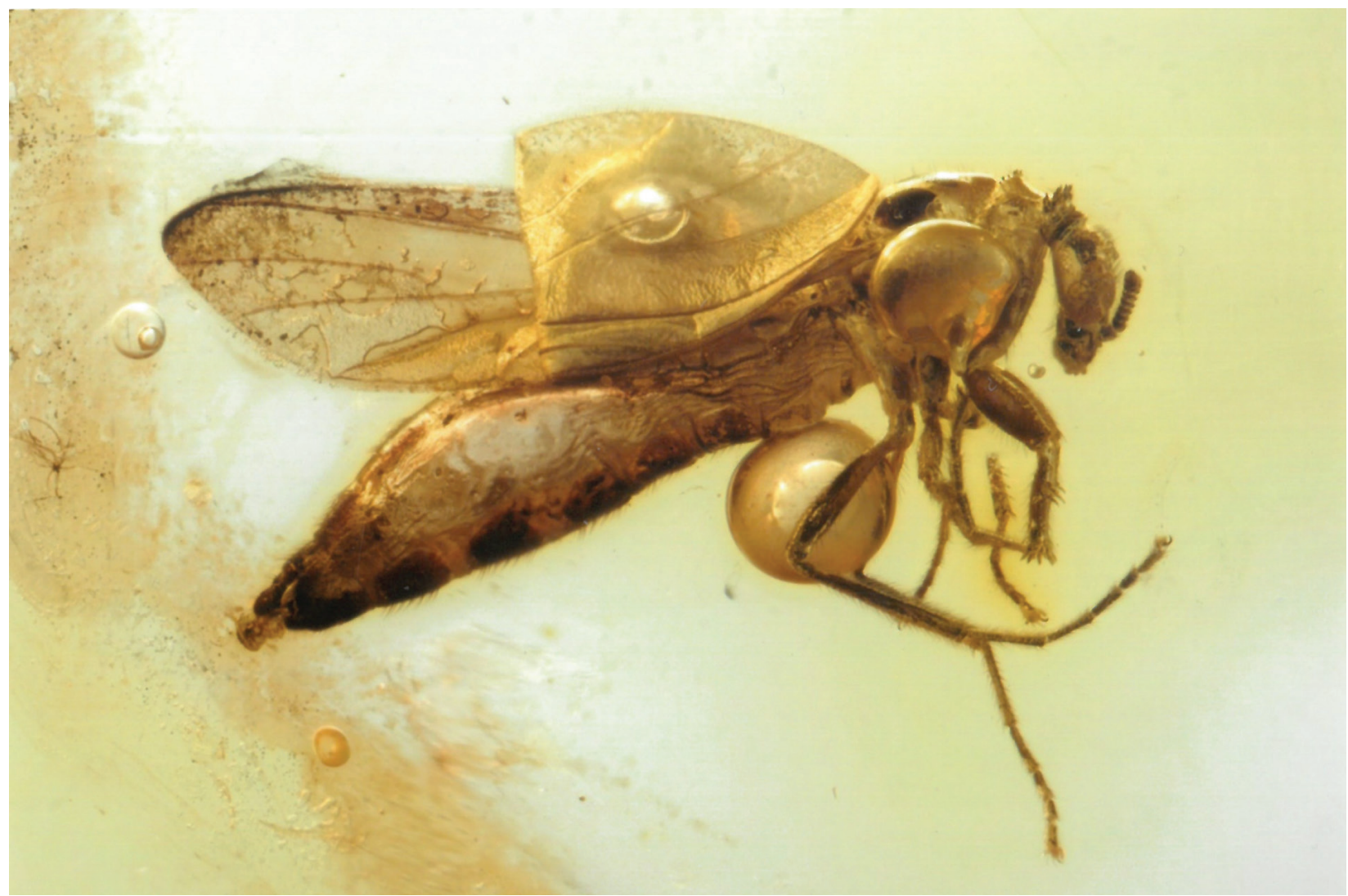

Figure 11. Dilophus sp., female. JS-Baltic-011. Photo: Jonas Damzen.

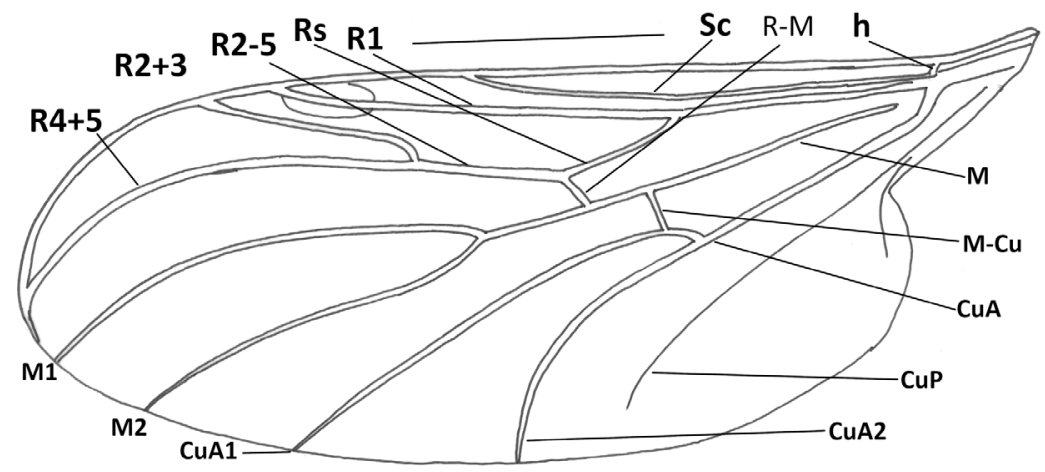

Figure 12. Hesperinus electrus, male, wing. Scale bar: $1 \mathrm{~mm}$.

little curved basad. $\mathrm{CuA}_{1}$ straight, $\mathrm{CuA}_{2}$ apically strongly curved basad. CuP fine, gently curved, reaches wing edge. Length of wing veins in $\mathrm{mm}(\mathrm{N}=2)$ subcosta $2.2-$ 2.3, basal R 1.0-1.3, distal $\mathrm{R}_{1} 1.5-1.6$, Rs $0.45-0.55, \mathrm{R}_{2-5}$ $0.62-0.65, \mathrm{R}_{2+3} 0.75-0.91, \mathrm{R}_{4+5} 1.6-1.8, \mathrm{R}-\mathrm{M} 0.14$, basal M 1.4, distal M 0.30-0.38, M 1.8, M $1.5-1.6, \mathrm{M}-\mathrm{Cu}$ 0.10-0.15, CuA 1.0-1.4, CuA 1.7-2.0, $\mathrm{CuA}_{2}$ 1.3-1.6.

Legs: Dark brown, long and slender, clad with strong, short, dark pile. Fore tibia with one, mid- and hind-tibiae with two short, straight, dark spurs. Tarsi very slender. Leg measurements ( $\mathrm{N}=2$ unless otherwise stated) fore femur 1.4-1.5 mm long, fore tibia $1.4 \mathrm{~mm}$ long $(\mathrm{N}=1)$, fore first tarsomere $0.77 \mathrm{~mm}$ long $(\mathrm{N}=1)$, mid femur $1.5 \mathrm{~mm}$ long $(\mathrm{N}=1)$, mid tibia $1.3 \mathrm{~mm}$ long $(\mathrm{N}=1)$, hind femur 1.6-1.9 mm long, $0.12 \mathrm{~mm}$ wide $(\mathrm{N}=1)$, hind tibia 1.8-2.1 mm long, $0.09 \mathrm{~mm}$ wide $(\mathrm{N}=1)$, hind first tarsomere $0.86 \mathrm{~mm}$ long $(\mathrm{N}=1)$.

Abdomen: Dark brown, cylindrical, slender, rather densely clad with dark brown pile. Length $3.1 \mathrm{~mm}$, width $0.5 \mathrm{~mm}(\mathrm{~N}=1)$.

Terminalia (Fig. 14): Width of hypopygium $0.47 \mathrm{~mm}$ $(\mathrm{N}=1)$. Hypopygium slightly expanding apicad, clad with short, dark pile. Gonostylus curved and sharply pointed, $0.24 \mathrm{~mm}$ long $(\mathrm{N}=1)$. Posterior edge of gonocoxosternite almost straight. Epandrium apparently quite small, not possible to see clearly, probably rounded-rectangular. Ejaculatory apodeme large and prominent, apically dome-shaped. 


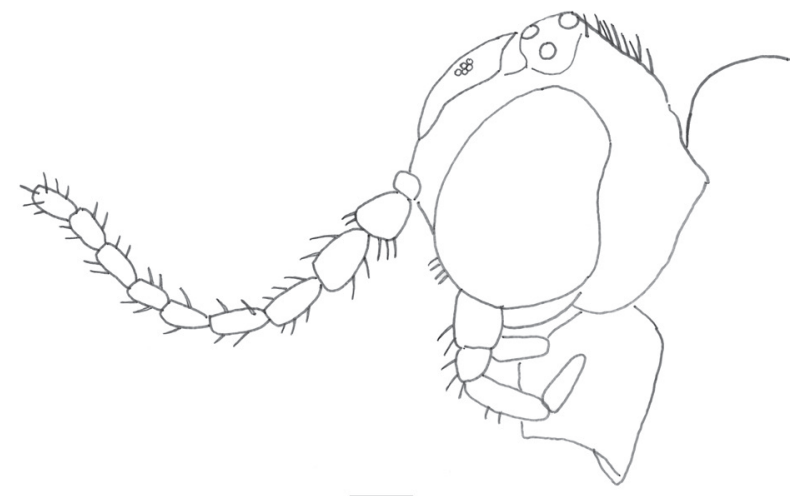

Figure 13. Hesperinus electrus, male, head. Scale bar: $0.1 \mathrm{~mm}$.

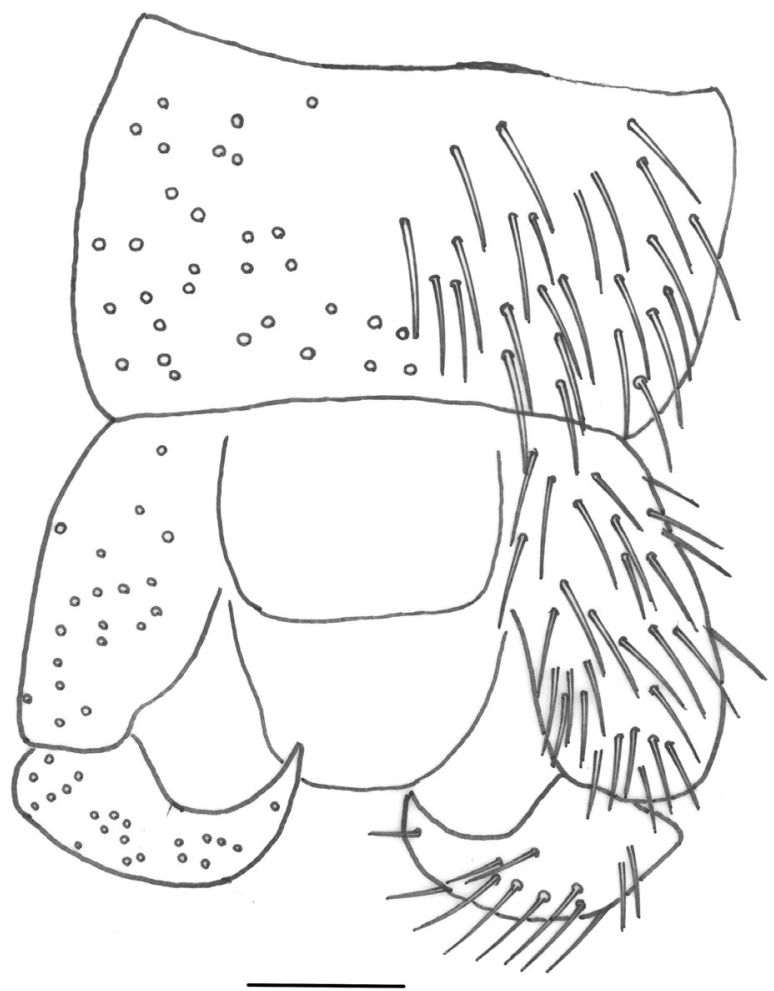

Figure 14. Hesperinus electrus, male, terminalia. Scale bar: $0.1 \mathrm{~mm}$

Discussion. The original description was found to contain some errors, e.g., the flagellum has eight, not seven segments, and is shorter than stated in the description. The poorly developed mouthparts suggest that this species did not feed in the adult stage, this may be a general trait for Hesperinus species as all seem to have very small mouthparts. The genus Hesperinus has frequently been referred to a separate family, the Hesperinidae (e.g., Krivosheina 1997). However, molecular evidence suggests that the genus belongs in the Bibionidae (Ševčik et al. 2016) and this is also supported by fossil material, where Hesperinus and Penthetria species look far more similar than in the modern species. Hence, I prefer to place Hesperinus and Penthetria together in the subfamily Hesperininae in Bibionidae (Skartveit and Ansorge 2020).
Penthetria montanaregis Skartveit, 2009: 13

Figs 2, 15-17

Note. The species was described based on a single, male specimen (Skartveit 2009), however this specimen was to a large extent covered by white emulsion (Verlumung). The present specimen clarifies some aspects of the species' morphology.

Holotype, male, MHNN 972. Additional material, male, JS-Baltic-001, in piece of amber $39 \times 32 \times 3 \mathrm{~mm}$.

Redescription of the species. Male: Total length 6.3$7.9 \mathrm{~mm}(\mathrm{~N}=2)$. Colour uniormly dark, probably brownish-black in life.

Head (Fig. 16): Length $0.75 \mathrm{~mm}$, width $1.05 \mathrm{~mm}$ $(\mathrm{N}=1)$. Only just holoptic, complex eyes in contact only 2-3 ommatidia, meeting at distance similar to diameter of ocellar tubercle anterior to tubercle. Complex eye nearly bare, with very short, fine and sparse intraocular hairs. Ocellar tubercle small but fairly prominent, with few strong, short, dark brown setae on posterior face. Rostrum not protruding. Palp not possible to see in this specimen. Antenna: flagellum slightly conical, 8-segmented, $0.58 \mathrm{~mm}$ long, $0.09 \mathrm{~mm}$ wide, segments subquadrate when seen laterally.

Thorax: Length 1.35-1.84 $\mathrm{mm}(\mathrm{N}=2)$, width $1.16 \mathrm{~mm}$ ( $\mathrm{N}=1$, smaller specimen). Dorsal side covered by Verlumung, surface structure not possible to see. With irregularly biseriate, short and fine, dark dorsocentral setae, notum otherwise practically bare. Haltere brown.

Wing (Fig. 15): Length approximately $5.6 \mathrm{~mm}$, width $2.0 \mathrm{~mm}$, length/width $=2.8(\mathrm{~N}=1)$. The wing is somewhat crumbled, exact vein measurements difficult to find. Brown fumose, costal cell mostly darkened, but unpigmented basally of humeral crossvein. Pterostigma and veins dark brown, distinctive but not particularly strong. Costa with fine setulae, veins otherwise bare. Costa extends a little beyond apex of $\mathrm{R}_{4+5}$. Humeral crossvein rather strong, vertical. Subcosta distinctive, relatively strong, but merges with $\mathrm{R}$ at humeral crossvein, not visible basally. $\mathrm{R}_{2+3}$ fine, straight, oblique, about $0.4 \times$ length of $\mathrm{R}_{4+5} . \mathrm{R}_{4+5}$ moderately curved. $\mathrm{R}-\mathrm{M}$ vertical. $\mathrm{M}$ basally not connected to $\mathrm{R}$ nor to $\mathrm{CuA}$. Fork of $\mathrm{M}$ rather narrow. $\mathrm{M}-\mathrm{CuA}$ pigmented only in posterior half (nearest $\mathrm{CuA}_{1}$ ). $\mathrm{CuA}_{1}$ rather straight, $\mathrm{CuA}_{2}$ bent caudad in apical fourth. $\mathrm{CuP}$ not prominent. Vein lengths, all in $\mathrm{mm}$ : Basal $\mathrm{R} 2.25$, Rs $0.86, \mathrm{R}_{2-5} 0.36, \mathrm{R}_{2+3} 0.68, \mathrm{R}_{4+5} 1.58, \mathrm{R}-\mathrm{M} 0.17$, basal M 2.25, distal M 0.45, M 2.06, M 1.61, M-CuA 0.15, CuA 1.54, $\mathrm{CuA}_{1} 2.44, \mathrm{CuA}_{2} 1.73$.

Legs: Dark brown, densely clad with strong, short, dark setae. Femorae moderately clavate, all tibiae and tarsi slender. Tibial spurs dark, straight and sharp.

Abdomen: Length $4.1 \mathrm{~mm}$, width $0.9 \mathrm{~mm}(\mathrm{~N}=1)$, slightly conical. Tergites shiny, brownish-black, with fine and rather short, dark brownish pile.

Terminalia (Fig. 17): Width of hypopygium $0.71 \mathrm{~mm}$ $(\mathrm{N}=1)$. Epandrium bilobate, lobes rounded with dense, rather long, dark brown setae. Gonocoxite with robust, 


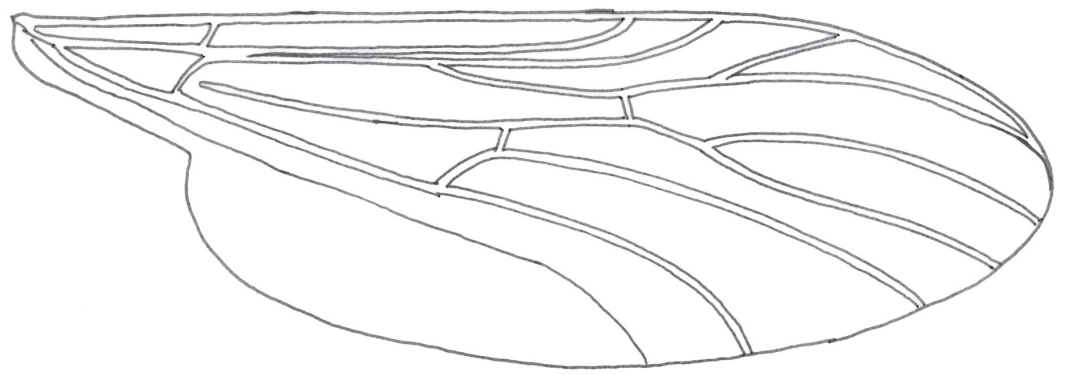

Figure 15. Penthetria montanaregis, male, wing. Scale bar: $1 \mathrm{~mm}$.

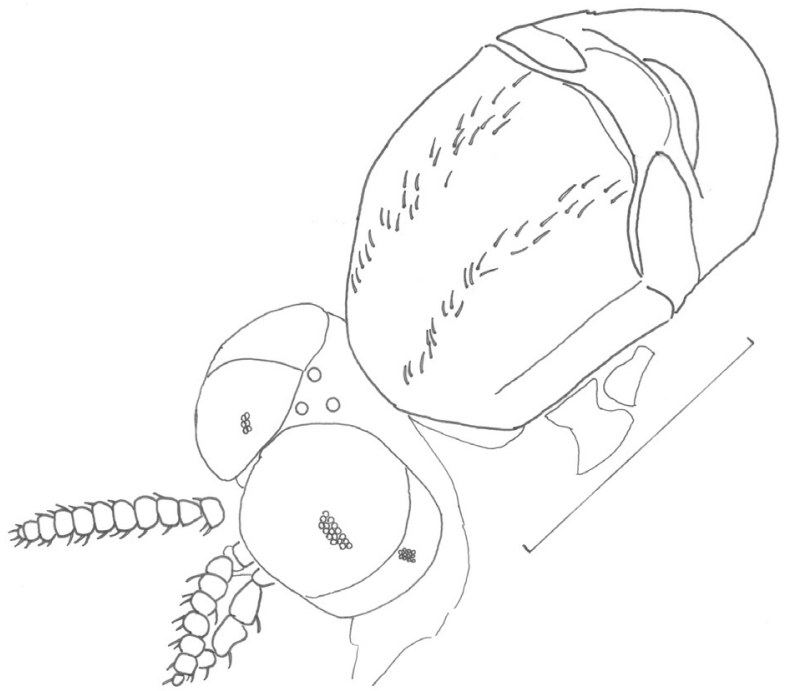

Figure 16. Penthetria montanaregis, male, head and thorax. Scale bar: $1 \mathrm{~mm}$.

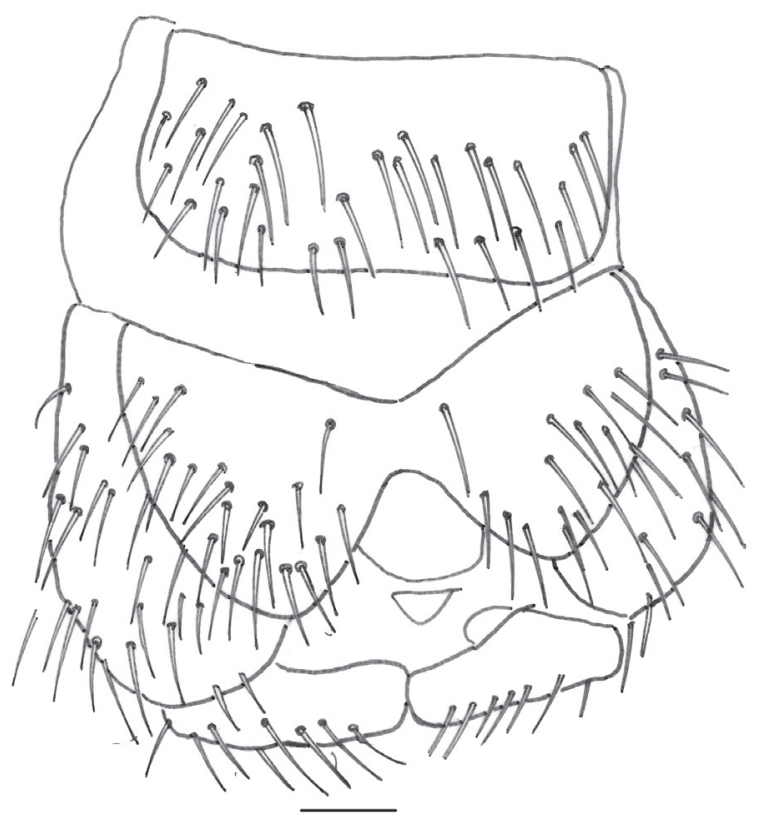

Figure 17. Penthetria montanaregis, male, terminalia. Scale bar: $0.1 \mathrm{~mm}$. dark brown setae, Gonostylus length $0.39 \mathrm{~mm}$, rather long, straight, apically a little expanded, on posterior margin with about 8 strong, dark brown setae. (note: the apparent shape of the gonostylus is rather different from the holotype of Penthetria montanaregis, but this is probably due to preservation in different angles. The apparent shape of the gonostylus in male Bibionidae is extremely dependent on perspective). Ejaculatory apodeme rather wide.

\section{Penthetria sp.}

Figs 3, 18

Material. Female, SDEI Dip-00823 - CCHH\#1789-4, embedded in a clear amber block which has undergone autoclave treatment (C. Hoffeins, in litt.).

The species differs from Penthetria montanaregis in the following aspects: smaller, wing length about $4.5 \mathrm{~mm}$, wing narrower, more than 3 times as long as wide (in bibionids, females generally have wider wings than conspecific males) with reduced anal lobe, $\mathrm{R}_{2+3}$ placed more distally so that the segment $\mathrm{R}_{2-5}$ is almost as long as $\mathrm{R}_{4+5}$ (less than half as long in P. montanaregis), fork of $\mathrm{M}$ strongly asymmetrical (nearly symmetrical in P.montanaregis), $\mathrm{CuA}_{2}$ apically strongly curved basad (moderately curved basad in P. montanaregis). It differs from female Penthetria integroneura Skartveit, 2009 most conspicuously by the presence of $\mathrm{R}_{2+3}$ and by the more strongly curved $\mathrm{CuA}$-veins, also by the presence of strong setae dorsally on the thorax and apparently by the head shape, though the latter is likely affected by autoclave treatment.

Description. Male unknown.

Female $(\mathrm{N}=1)$ : Total length $5.0 \mathrm{~mm}$. The specimen is of a uniform, dark colour, likely affected by the autoclaving.

Head: length $0.58 \mathrm{~mm}$. Apparent shape probably affected by autoclaving, outline of complex eye not possible to see. Flagellum $0.42 \mathrm{~mm}$ long, $0.07 \mathrm{~mm}$ wide, 7-segmented, shape of flagellomeres obviously affected by autoclaving. Palp relatively long, outer segments appear to be very slender, but this is likely an artefact caused by autoclaving.

Thorax: Length $1.18 \mathrm{~mm}$. Dorsally with some relatively long and strong, erect setae, details otherwise not possible to make out. Haltere light brown. 


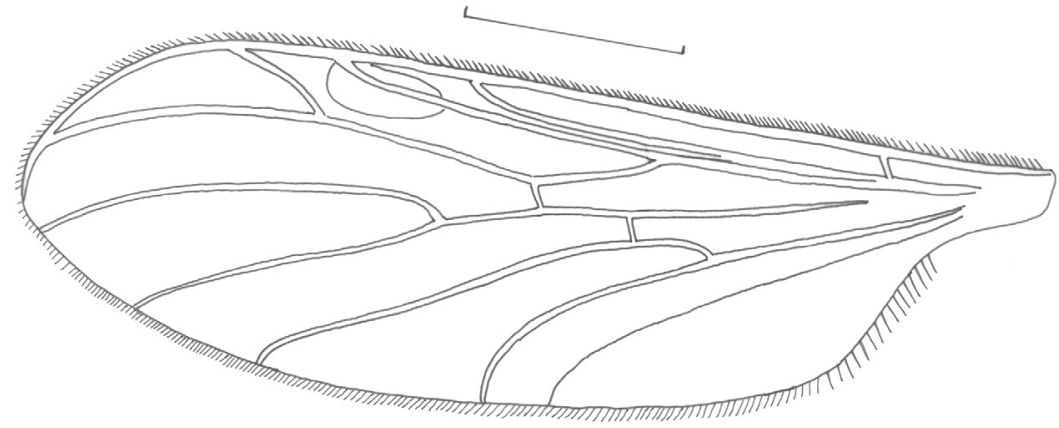

Figure 18. Penthetria sp., female, wing. Scale bar: $1 \mathrm{~mm}$.

Legs: relatively long, femorae slightly clavate, tibiae apparently very slender (possibly affected by autoclaving). The legs are clad with relatively long, brown pile, on tibiae about as long as the tibia's width. Tibial spurs fine and sharp. Segment measurements, all inn mm: fore femur length 1.37 , width 0.16 , fore tibia length 1.32 , width 0.12 , mid femur length 1.23 , hind femur length 1.69 , width 0.18 , hind tibia length 1.71 , width 0.13 , hind first tarsomere length 0.63 , width 0.07 .

Wing (Fig. 18): Length $4.6 \mathrm{~mm}$, width $1.5 \mathrm{~mm}$, length $/$ width $=3.1$. Brown fumose, relatively slender, veins brown throughout, R-veins considerably more robust than $\mathrm{M}$ - and $\mathrm{CuA}$-veins. Costa relatively strong with rather long setules which at least basally are longer than the width of the vein, extending a little past halfway between apices of $\mathrm{R}_{4+5}$ and $\mathrm{M}_{1}$. Humeral vein present, oblique. Pterostigma relatively small, oval, brown. Subcosta fine but distinctive, straight. $\mathrm{R}_{2+3}$ oblique, almost straight, a little less than half as long as $\mathrm{R}_{4+5}$, which is gently curved. Rs straight, nearly three times as long as $\mathrm{R}-\mathrm{M}$, which is vertical. $\mathrm{R}_{2-5}$ (basally of $\mathrm{R}_{2+3}$ ) almost as long as $\mathrm{R}_{4+5}$ (distally of $\mathrm{R}_{2+3}$ ). M basally connected to $\mathrm{CuA}$. M-veins fine, $\mathrm{M}$ and $\mathrm{M}_{2}$ form an approximately straight line with $\mathrm{M}_{1}$ diverging forward from this. $\mathrm{CuA}$ apically slightly, $\mathrm{CuA}_{2}$ strongly bent basad. CuP parallel to $\mathrm{CuA} / \mathrm{CuA}_{2}$, fine but does reach wing margin. Anal lobe strongly reduced, basal-posterior edge of the wing nearly straight-lined. Vein lengths, all in mm: Subcosta 2.48 , Basal R 1.46, $\mathrm{R}_{1} 1.44$, Rs 0.53, $\mathrm{R}_{2-5} 1.09, \mathrm{R}_{2+3}$ $0.58, \mathrm{R}_{4+5} 1.27$, R-M 0.19, basal M 1.41, distal M 0.44, $\mathrm{M}_{1}$ 1.85, M 1.41, M-CuA 0.14, CuA 1.02, CuA 1.99, $\mathrm{CuA}_{2} 1.18$. The wings have numerous, transverse cracks probably caused by autoclaving, this has not altered the overall shape, though.

Abdomen: Length $3.6 \mathrm{~mm}$, dark, cylindrical, with fine, dark, short pile. Shape of terminalia difficult to make out, probably affected by autoclaving.

Discussion. The specimen of this species is obviously affected by autoclave treatment, particularly so in the head where the overall shape appears changed, the outlines of the complex eyes are not possible to make out, and the shapes of the antennal and palp segments are strongly disrupted. The autoclaving appears also to have altered the appearance of the terminalia, and possibly tho- rax and legs to some extent. However, the wing characters appear to be uncompromised and should be sufficient to recognise the species, at the very least to differentiate it from the other species of Penthetria known from Baltic amber. Identifying Penthetria species based on female specimens is very difficult in recent species and this is probably so in fossil species, too, hence this specimen is not given a formal name at this stage.

\section{Plecia clavifemur Skartveit, 2009: 15-16}

Fig. 4

Type material, females. Holotype, SDEI Dip-00830 - CCHH\#1474.2. Paratypes SDEI Dip-00845 CCHH\#1505.1; SDEI Dip-00846 - CCHH\#1501.5.

Additional material, females. JS-Baltic-002, in piece of amber $20 \times 15 \times 4 \mathrm{~mm}$, JS-Baltic-003, in piece of amber $18 \times 13 \times 6 \mathrm{~mm}$. These specimens do not reveal any characters not seen in the type material, but their morphometric data is given below.

Total length $3.47-4.62 \mathrm{~mm}$.

Head: Length $0.42 \mathrm{~mm}(\mathrm{~N}=1)$, width $0.57-0.60 \mathrm{~mm}$. Flagellum length $0.40-0.47 \mathrm{~mm}$, width $0.08 \mathrm{~mm}(\mathrm{~N}=2)$. Thorax: Length 0.83-0.92 mm.

Legs: Fore femur $0.66-0.79 \mathrm{~mm}$ long, $0.12-0.15 \mathrm{~mm}$ wide, fore tibia $0.75-1.11 \mathrm{~mm}$ long, $0.08-0.09 \mathrm{~mm}$ wide, fore first tarsomere $0.24-0.38 \mathrm{~mm}$ long, $0.05-0.07 \mathrm{~mm}$ wide, fore second to fifth tarsomeres $0.19,0.13,0.11$ and $0.15 \mathrm{~mm}$ long $(\mathrm{N}=1)$. Mid femur $0.88 \mathrm{~mm}$ long, $0.15 \mathrm{~mm}$ wide $(\mathrm{N}=1)$, mid tibia $0.69 \mathrm{~mm}$ long, $0.08 \mathrm{~mm}$ wide $(\mathrm{N}$ $=1$ ). Hind femur $0.90-1.24 \mathrm{~mm}$ long, $0.11-0.15 \mathrm{~mm}$ wide, hind tibia $0.97-1.20 \mathrm{~mm}$ long, $0.08-0.12 \mathrm{~mm}$ wide, hind first tarsomere $0.23-0.41 \mathrm{~mm}$ long, $0.07-0.09 \mathrm{~mm}$ wide.

Wing: length $3.05-3.11 \mathrm{~mm}$, width $1.00-1.39 \mathrm{~mm}$, length/width $=2.24-3.05$. Vein lengths, all in $\mathrm{mm}$ : Subcosta 1.50-1.58, basal R 1.00-1.13, distal $\mathrm{R}_{1}$ 0.75-0.85, Rs $0.27-0.38, \mathrm{R}_{2-5} 0.58-0.83, \mathrm{R}_{2+3} 0.16-0.23, \mathrm{R}_{4+5} 0.64$ 0.68, R-M 0.07-0.17, basal M 0.92-1.05, distal M 0.330.34, M 1.20-1.37, M 0.88-1.00, M-CuA $0.11(\mathrm{~N}=1)$, CuA 0.67-0.79, $\mathrm{CuA}_{1}$ 1.12-1.54, $\mathrm{CuA}_{2}$ 0.58-1.16.

Abdomen: Length $2.5 \mathrm{~mm}(\mathrm{~N}=1)$.

Discussion. The two specimens examined are similar in the shape of the head and antenna, general aspects of 
wing venation (short $\mathrm{R}_{2+3}$, kinked $\mathrm{R}_{4+5}, \mathrm{CuA}_{2}$ bent sharply basad) and terminalia, however they are rather different with respect to some morphometric traits, particularly length of leg segments and the general shape of the wing. At the present state of knowledge I interpret this difference as within intraspecific variation, though additional material, particularly if male specimens are found, may reveal that there are more than one species involved.

\section{Plecia hoffeinsorum Skartveit, 2009: 17-19}

Figs 5-7, 19-23

Plecia tenuicornis Skartveit, 2009: 20-22. Syn.n.

Type material. Holotype (male) of Plecia hoffeinsorum SDEI Dip-00827 - CCHH\#1448-2, preserved together with six conspecific males. Paratype (male) SDEI Dip00843 - CCHH\#1629-2. Holotype (male) of Plecia tenuicornis SDEI Dip-00828 - CCHH\#1501-2. Paratypes (males): SDEI Dip-00837 - CCHH\#335-2. SDEI Dip00838 - CCHH\#935-2. SDEI Dip-00839 - CCHH\#10251. SDEI Dip-00840 - CCHH\#1025-2. SDEI Dip-00841 - CCHH\#1567-3. SDEI Dip-00843 - CCHH\#1629-2 (Preserved together with holotype). Previously studied non-type, female, CCHH\#1501-3.

New material, Baltic amber: males: JS-Baltic-004, in piece of amber $27 \times 20 \times 6 \mathrm{~mm}$, syninclusions: cecidomyiid midge, 2 phorid flies; JS-Baltic-005, in piece of amber $16 \times 12 \times 4 \mathrm{~mm}$. JS-Baltic-007, in piece of amber
$22 \times 13 \times 6$ mm. Females: SDEI In 001701 (syninclusion with Sciarid midge); JS-Baltic-006, in piece of amber $13 \times 7 \times 3 \mathrm{~mm}$. Rovno amber, male: JS-Baltic-008, in rather large piece of amber $36 \times 20 \times 15 \mathrm{~mm}$, syninclusions: copious plant debris, possibly flower fragments.

The species was described based on seven male specimens preserved together in one piece of amber. The present specimens do show the male terminalia better than the type material, hence this is redecribed here, otherwise the external morphology is adequately described in the original descriptions of Plecia hoffeinsorum and Plecia tenuicornis (Skartveit 2009: 17-22). The female of Plecia hoffeinsorum was described from a compression fossil from Grube Messel (Skartveit and Wedmann 2016). The two species Plecia hoffeinsorum and Plecia tenuicornis were originally thought to have rather different male terminalia (Skartveit 2009, figs 34, 35, 46, 47), however studying additional specimens suggests that the two "forms" are actually the same structure with the gonostylus fixed in different positions. As usual with Bibionidae the angle of view is quite critical when studying these structures.

Measurements, including new material. Males: body length $4.5-5.2 \mathrm{~mm}(\mathrm{~N}=4)$, thorax length 0.92 $1.30 \mathrm{~mm}(\mathrm{~N}=8)$, wing length $4.0-5.2 \mathrm{~mm}(\mathrm{~N}=6)$. Females: body length $4.5-4.6 \mathrm{~mm}(\mathrm{~N}=2)$, thorax length $0.97-1.17 \mathrm{~mm}(\mathrm{~N}=2)$, wing length $4.6 \mathrm{~mm}(\mathrm{~N}=1)$. Wings as in Figs 19, 20, head as in Figs 21, 22.

Redescription of male terminalia (Fig. 23). Hypopygium width $0.43 \mathrm{~mm}(\mathrm{~N}=1)$, outline almost rectangular, slightly expanded apicad. Gonostylus $0.22 \mathrm{~mm}$

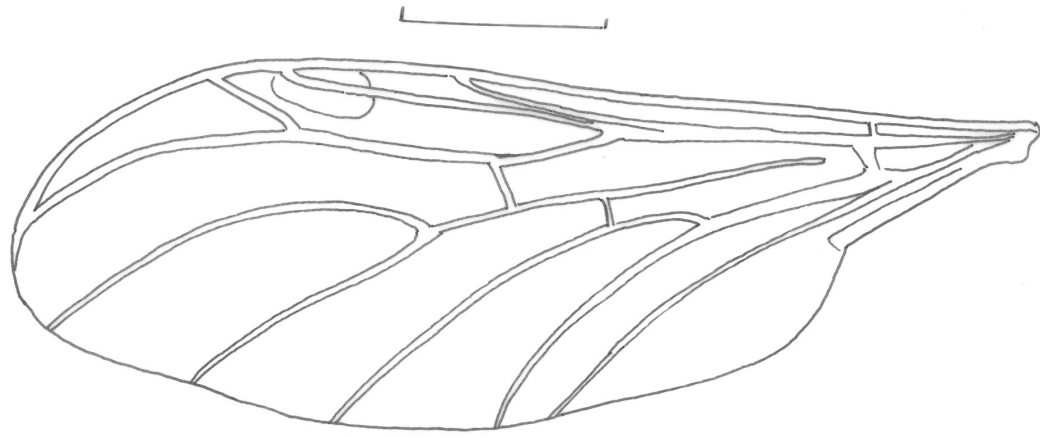

Figure 19. Plecia hoffeinsorum, male, wing. Scale bar: $1 \mathrm{~mm}$.

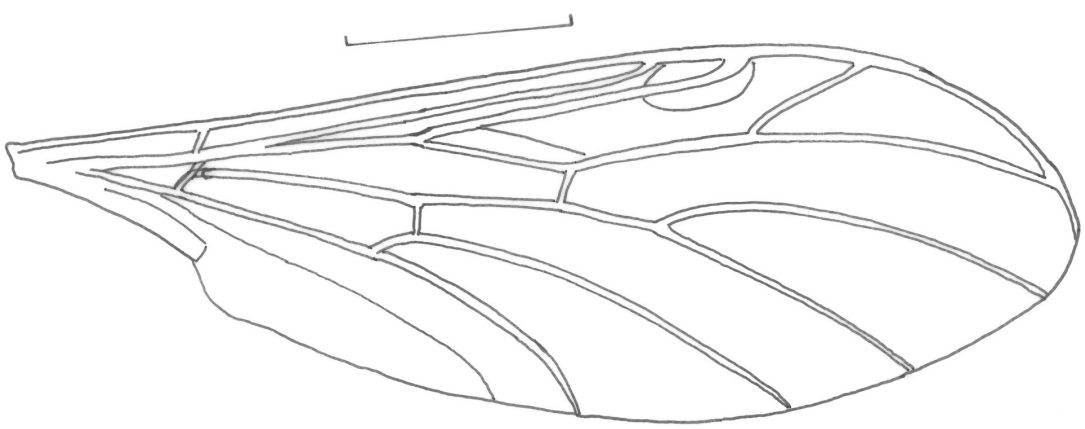

Figure 20. Plecia hoffeinsorum, female, wing. Scale bar: $1 \mathrm{~mm}$. 


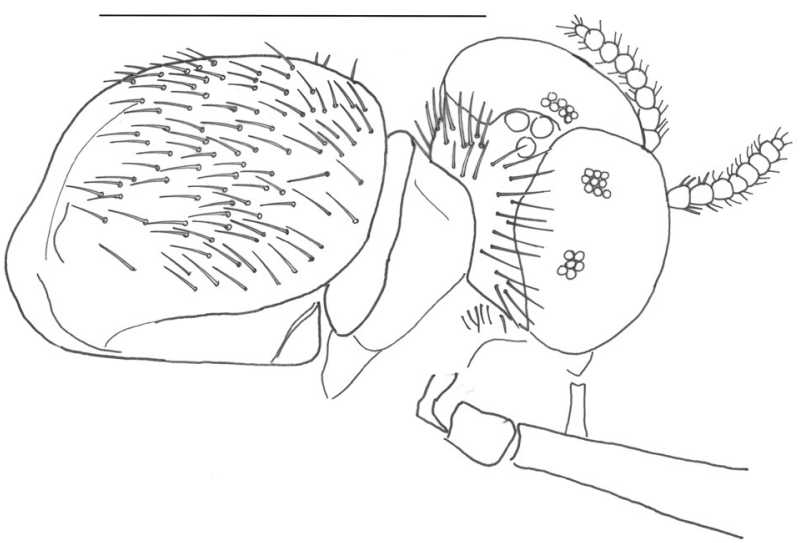

Figure 21. Plecia hoffeinsorum, male, head and thorax. Scale bar: $1 \mathrm{~mm}$.

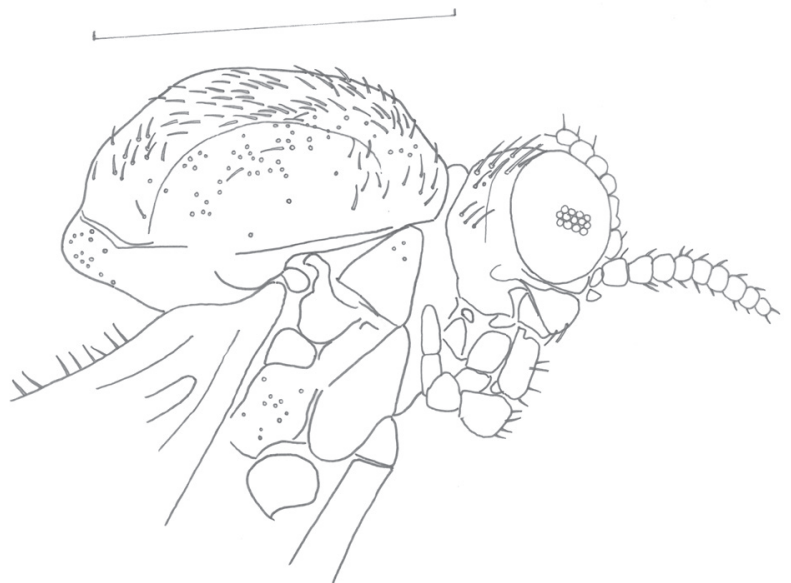

Figure 22. Plecia hoffeinsorum, female, head and thorax. Scale bar: $1 \mathrm{~mm}$.

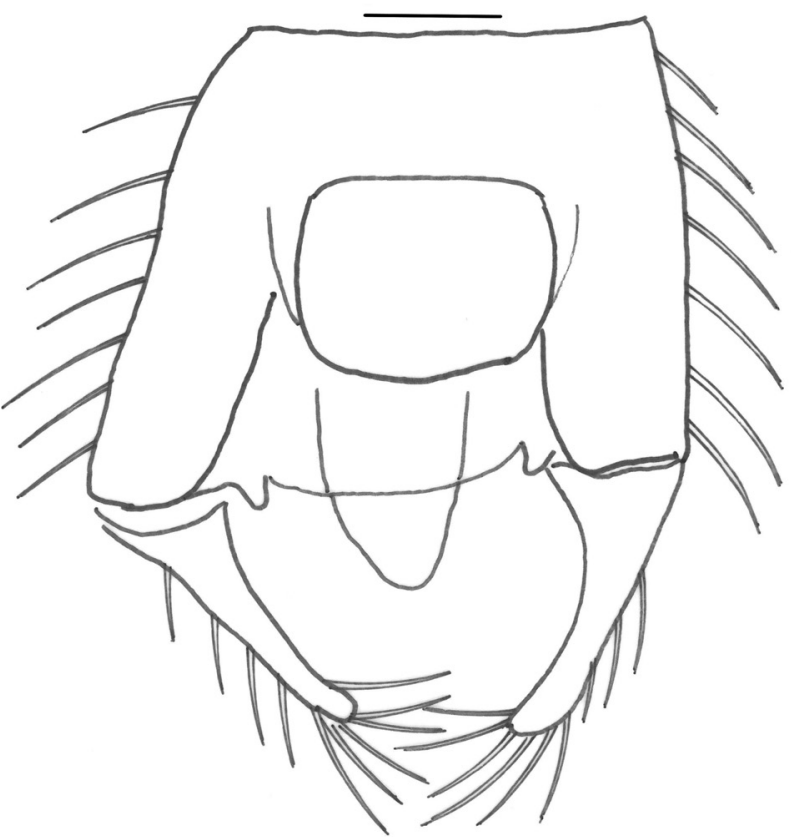

Figure 23. Plecia hoffeinsorum, male, terminalia. Scale bar: $0.1 \mathrm{~mm}$. long, attached apically on gonocoxite, long and slender, straight, apically somewhat pointed, with numerous long, curvy setae. Epandrium rather small, rounded-rectangular, posterior edge sligthly convex. Gonocoxosternite apically with a short, blunt tooth on each side just mesal to gonostylus attachment, posterior edge slightly convex.

\section{Bibio succineus sp. nov.}

http://zoobank.org/2482E3D0-F1D5-443E-B236-BB1AEA235979

Figs 8, 24-28

Type material. Holotype (male), SDEI Dip-00900 - JS-Baltic-009. The specimen is preserved in a piece of yellowish amber, $30 \times 17 \times 6 \mathrm{~mm}$. Syn-inclusion: one sciarid gnat.

Additional material (female) Coll. Kernegger $59 / 2006$. The specimen was briefly described by Skartveit (2009: 26-27).

Comparison to other species. Four species of Bibio have been described from the Eocene/Oligocene of Isle of Wight (Krzeminski et al. 2019). Of these, Bibio gurnetensis Cockerell, 1917 and Bibio oblitus Cockerell, 1921 both have crossvein R-M much longer than the basal Rs, this character suggests the species belong in the genus Dilophus, though, not having seen the original material, I will not make a formal transfer here. Bibio extremus Cockerell, 1921 differs from the present species in that the basal part of Rs is quite steep and that crossvein $\mathrm{M}-\mathrm{Cu}$ meets $\mathrm{M}_{2}$ considerably distally of furcation. Bibio oligocenus Cockerell, 1917, which despite the name was described from the late Eocene, differs from the present species by being larger (wing length $8 \mathrm{~mm}$ ) with a conspicuously darkened costal cell in the wing.

Etymology. The epithet is derived from Latin succinum, amber, referring to the preservation of the type specimen. It is the first species of the genus Bibio described from amber fossils.

Diagnosis. A medium-sized Bibio, body length about $7.5 \mathrm{~mm}$. Body and legs entirely black, densely pilose, pile on thorax and abdomen pale, black on legs. Antennal flagellum 8-9-segmented. Haltere pale brown. Wing light brownish fumose in male, brown fumose in female, pterostigma pale and indistinctive, radial sector about four times as long as R-M. Fore tibia with spur a little less than half as long as spine. Hind tarsus not enlarged.

Description. Male $(\mathrm{N}=1)$ : Total length $7.5 \mathrm{~mm}$, entirely black.

Head (Fig. 25): Length $1.37 \mathrm{~mm}$, width not possible to measure. Complex eye with rather dense, pale, fine, medium-length intraocular pile. Ocellar tubercle not prominent, with short, dark setae. Rostrum not prominent. Antenna: flagellum 8-segmented, $0.53 \mathrm{~mm}$ long, $0.13 \mathrm{~mm}$ wide. Two distal palp segments slender (more basal segments not possible to see).

Thorax: Length $2.2 \mathrm{~mm}$, black, very shiny. Pile pale, anteriorly rather short, getting longer in posterior part, sides of mesonotum and pleurae with long but rather sparse, pale pile. Sides of mesonotum with rather coarse, 


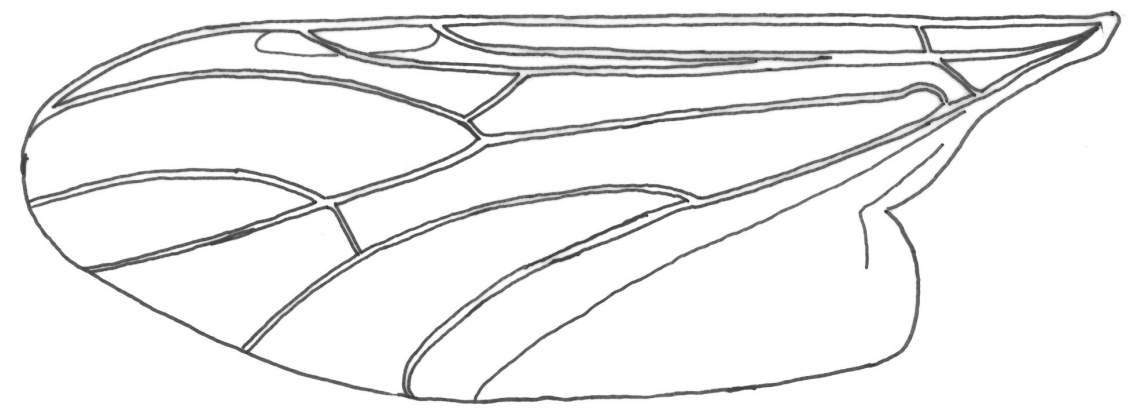

Figure 24. Bibio succineus sp. nov., male, wing. Scale bar: $1 \mathrm{~mm}$.

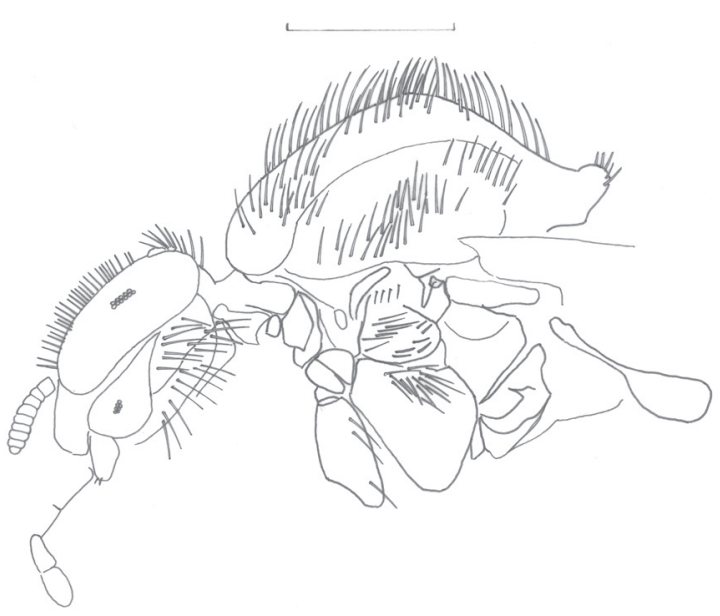

Figure 25. Bibio succineus sp. nov., male, head and thorax. Scale bar: $1 \mathrm{~mm}$.

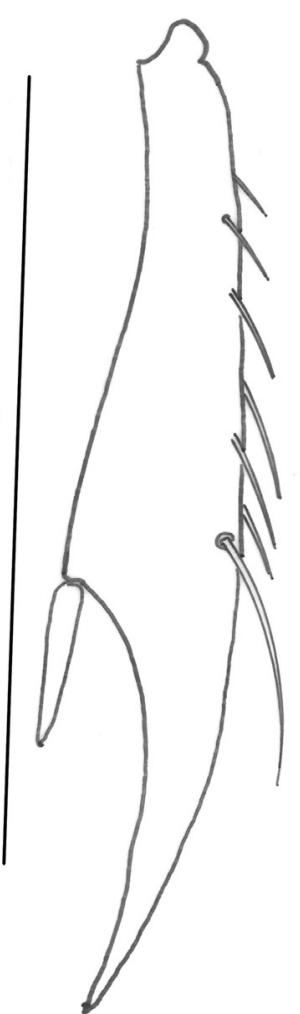

Figure 26. Bibio succineus sp. nov., male, fore tibia. Scale bar: $1 \mathrm{~mm}$ mesh-like microsculpture. Scutellum rounded with long, pale, proclinate setae along edge. Meron very shiny, in upper corner with about 20 long, pale hairs. Haltere pale brown, not possible to see well.

Wing (Fig. 24): Length $5.6 \mathrm{~mm}$, width $1.9 \mathrm{~mm}$, length/ width $=2.92$. Slightly brownish fumose, Costa and $\mathrm{R}_{1}$ light brown, posterior veins colourless. Pterostigma pale brown, inconspicuous, $0.45 \mathrm{~mm}$ long, $0.15 \mathrm{~mm}$ wide. Membrane without conspicuous microtrichia. Costa extends to apex of $\mathrm{R}_{4+5}$. Humeral vein present, fine and oblique. Subcosta weak, visible only in distal part. Basal radial sector about four times as long as crossvein R-M, M curves towards $\mathrm{R}_{1}$ at R-M. M basally clearly connected to $\mathrm{CuA}$. $\mathrm{M}-\mathrm{Cu}$ oblique, meets $\mathrm{M}$ at furcation. $\mathrm{CuA}_{1}$ apically moderately, $\mathrm{CuA}_{2}$ strongly curved basad. Vein lengths, all in mm: Basal $\mathrm{R} 2.51$, distal $\mathrm{R}_{1} 1.20$, Rs $0.39, \mathrm{R}_{4+5}$ 2.63, R-M 0.09, basal M 1.80, distal M 0.94, M 1.95, M 1.73, M-CuA 0.38, CuA 1.13, CuA 2.51, CuA 1.91 .

Legs: Black, clothed with short, strong, dark setae. Fore tibia (Fig. 26) with spur about half as long as spine. Hind femur (Fig. 28) basally thin, expanding at about $1 / 4$ of length, outer part stocky. Hind tibia rather slender, densely pilose, apparently without bare field of sensillae. Tarsus slender. Fore femur length $1.24 \mathrm{~mm}$, width $0.32 \mathrm{~mm}$, hind femur length $2.29 \mathrm{~mm}$, width $0.41 \mathrm{~mm}$, hind tibia length $2.25 \mathrm{~mm}$, width $0.26 \mathrm{~mm}$, hind first tarsomere $0.63 \mathrm{~mm}$ long, $0.18 \mathrm{~mm}$ wide, hind second to fifth tarsomeres length $0.38,0.28,0.23,0.37 \mathrm{~mm}$.

Abdomen: Black, clothed with rather short, fine, pale pile.

Terminalia: Gonostylus apically slender, rather straight. Hypopygium otherwise not possible to see.

Female (tentatively associated, $\mathrm{N}=1$ ): Total length $7.5 \mathrm{~mm}$, entirely black.

Head: Antennal flagellum 9-segmented. Occiput with short, dark setae. Complex eye rather small, rounded, with short, scattered, brownish intraocular pile.

Thorax: Mesonotum length $1.9 \mathrm{~mm}$. Covered by Verlumung in the specimen available. Haltere yellowish.

Wing: Brown fumose, membrane without microtrichia. Costa and R-veins brown, more posterior veins colourless. Basal radial sector about five times as long as crossvein R-M

Legs: black, rather stout. Length of fore femur $1.5 \mathrm{~mm}$, width $0.5 \mathrm{~mm}$, length of fore tibia $1.4 \mathrm{~mm}$, of hind tibia $2.2 \mathrm{~mm}$. Fore tibia (Fig. 27) with spine about three times 


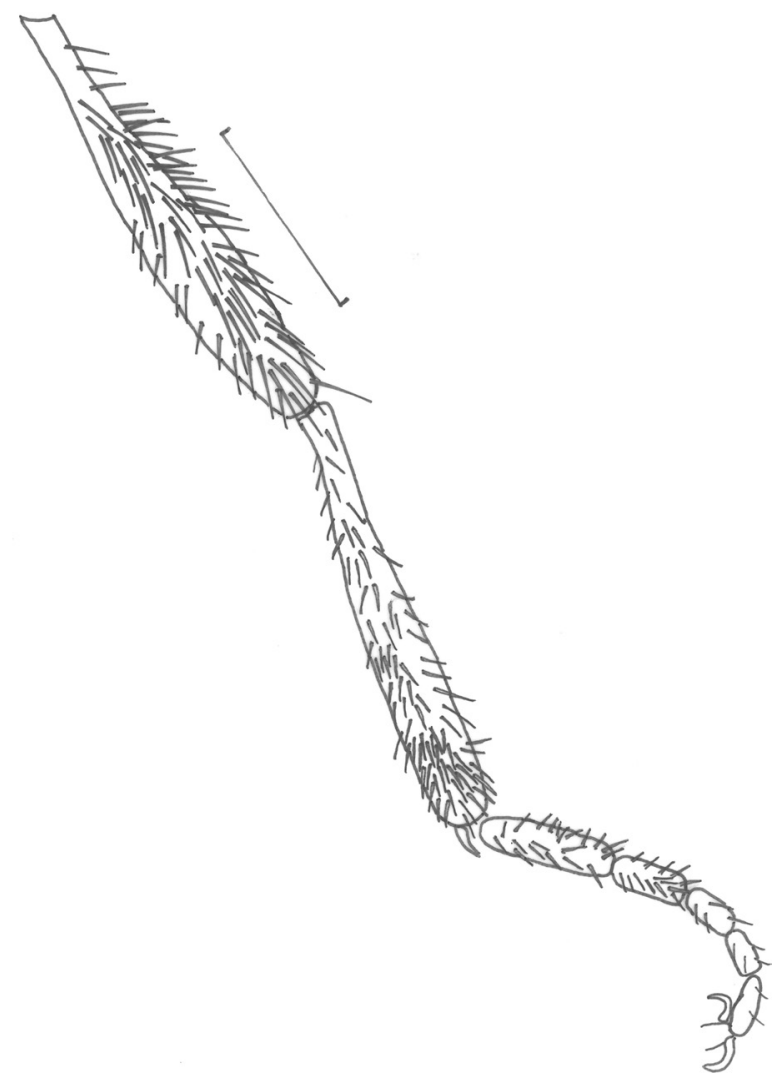

Figure 27. Bibio succineus sp. nov., male, hind leg. Scale bar: $1 \mathrm{~mm}$.

as long as spur, this is stout, straight and pointed. The tibia is clothed with quite long, fine setae and has a field of rounded coeloconical sensillae in the middle of the anterior face. The tarsi are quite slender.

Abdomen: cylindrical, no details possible to see.

Terminalia: no details possible to see.

\section{Dilophus crassicornis Skartveit, 2009: 31-34}

Figs 9, 29-31

Type material. Holotype, male, MHNN 907. Paratypes: males, SDEI Dip-00835 - CCHH\#932-4; SDEI Dip00836 - CCHH\#1629.1.

Non-type specimens previously examined. Male, MHNN 1412, females: CCHH\#932.2, CCHH\#1121.

Additional material. Female, CCHH \# 1789-2; female, JS-Baltic-012, in piece of amber $15 \times 8 \times 4 \mathrm{~mm}$.

Redescription, female. Total length $3.8-5.1 \mathrm{~mm}$ $(\mathrm{N}=3)$.

Head (Fig. 29): Length 0.62-0.77 $\mathrm{mm}(\mathrm{N}=3)$, width $0.59-0.60 \mathrm{~mm}(\mathrm{~N}=2)$, eye length $0.36-0.40 \mathrm{~mm}(\mathrm{~N}=2)$, width $0.27 \mathrm{~mm}(\mathrm{~N}=1)$. Flagellum 6-7-segmented, $0.32 \mathrm{~mm}$ long, $0.09 \mathrm{~mm}$ wide.

Thorax: Length 1.22-1.55 $\mathrm{mm}(\mathrm{N}=3)$, width $0.65 \mathrm{~mm}$ $(\mathrm{N}=1$, smallest specimen). Haltere light brown.

Wing: Length 3.44-3.75 mm $(\mathrm{N}=2)$. Hyaline, slightly brownish, veins fine and brown. Pterostigma brown. Costa extends to half-way between apices of $R_{4+5}$ and $M_{1}$.

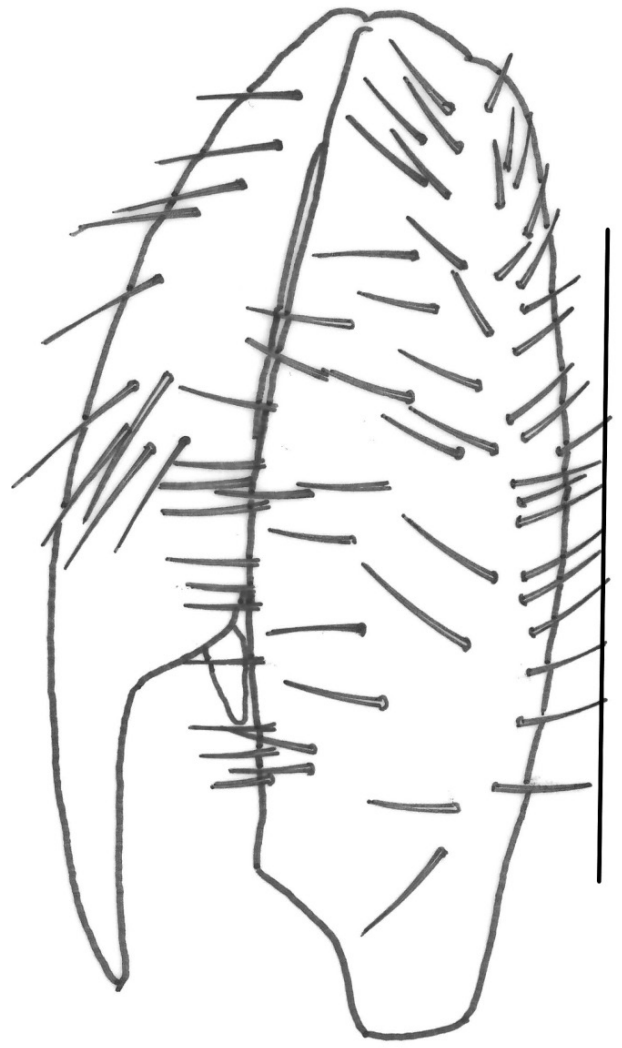

Figure 28. Bibio succineus sp. nov., female, fore leg. Scale bar: $1 \mathrm{~mm}$.

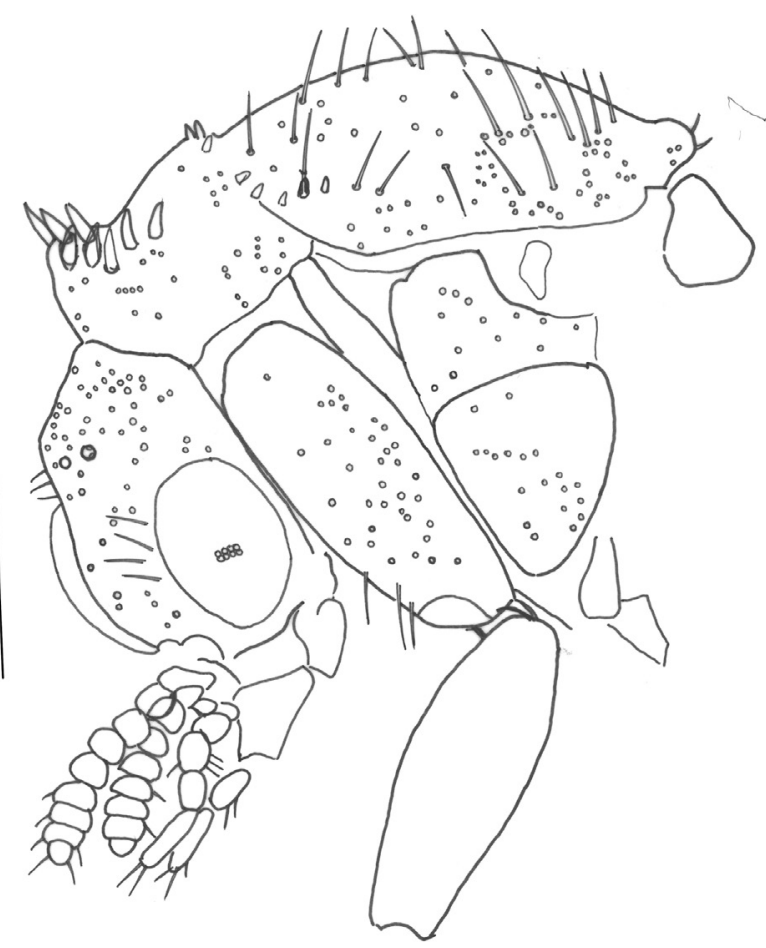

Figure 29. Dilophus crassicornis, female, head and thorax. Scale bar: $1 \mathrm{~mm}$.

Legs: Brown, sparingly clad with fine, short, brown pile. Fore tibia (Fig. 30) slightly sinuate, mesally with three long, erect, sharp spines, apically with spine circlet 


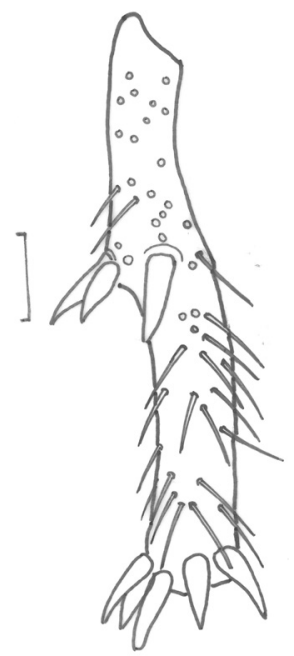

Figure 30. Dilophus crassicornis, female, fore tibia. Scale bar: $0.1 \mathrm{~mm}$.

of six long, diverging spines. Mid- and hind tibia apically with circlet of six spinose, brown setae. All tarsi slender. Measurements (all in mm, $\mathrm{N}=3$ unless otherwise stated) fore femur length $0.55-0.89$, width $0.25(\mathrm{~N}=1)$, fore tibia length $0.64-0.95$, width $0.09(\mathrm{~N}=1)$, fore first tarsomere length $0.40-0.44(\mathrm{~N}=2)$, mid femur length $0.70-0.92$, mid tibia length $0.72-0.90$, hind femur length $1.07-1.22$, width $0.14(\mathrm{~N}=1)$, hind tibia length $1.14-1.22$, width $0.13(\mathrm{~N}=1)$, hind first tarsomere length $0.50-0.62$.

Abdomen: Length $2.7 \mathrm{~mm}(\mathrm{~N}=1)$. Brown, conical. Terminalia in lateral view as in Fig. 31.

\section{Dilophus sp.}

Figs 10, 11, 32-34

Previously examined material. female, MHNN 711.

Material, females. JS-Baltic-010, in piece of amber $20 \times 12 \times 5 \mathrm{~mm}$; JS-Baltic-011, in piece of amber $29 \times 17 \times 3 \mathrm{~mm}$.

Two female specimens, belonging to the Dilophus febrilis-group, with 9 flagellomeres, so not fitting any of the previously described species which have 6-7 (Dilophus crassicornis) or 12 (Dilophus pseudofebrilis and Dilophus succineus) flagellomeres. They are likely to

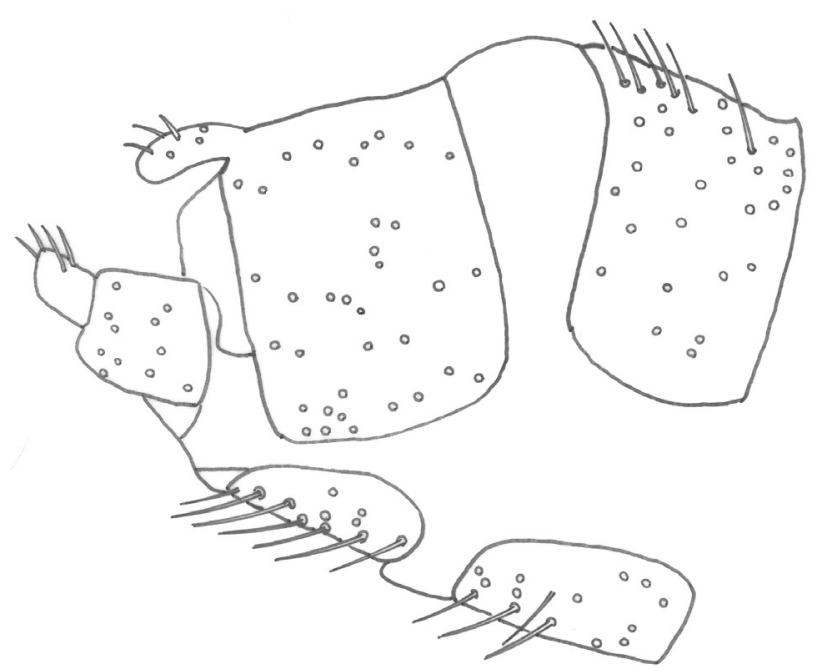

Figure 31. Dilophus crassicornis, female, terminalia, lateral view.

be conspecific with the poorly preserved specimen treated as Dilophus sp. by Skartveit (2009: 38). As the other species of Dilophus from Baltic amber are based on male specimens I find it not advisable to formally name this species at the present stage of knowledge. Males of this species, should they appear, should be recognizable by characters of the antenna and fore tibia.

Total length 4.55-5.68 mm. Body and legs entirely dark brown.

Head (Fig. 33): Length $0.68-0.80 \mathrm{~mm}$. Occiput, frons and gena all with strong, erect, relatively dense setae. Complex eye about half as long as head, somewhat protruding, with short and fine, rather dense intraocular pile. Ocellar triangle rather tall. Flagellum 9-segmented, 0.35$0.40 \mathrm{~mm}$ long, $0.06-0.08 \mathrm{~mm}$ wide. Palp shorter than antenna, with last segment conical, about 2.5 times as long as wide, bearing relatively long setae.

Thorax: Length 1.42-1.52 $\mathrm{mm}(\mathrm{N}=2)$, width $0.93 \mathrm{~mm}$ $(\mathrm{N}=1)$. Pronotal spine comb with 12 evenly spaced, medium-length, erect, sharp spines. Mesonotal spine comb with about 16 small, sharp spines. Mesonotum moderately shiny with uniserial, short and fine dorsocentral setae (about 15 on each side), otherwise mostly bare. Scutellum evenly clothed with fine, short setae. Haltere dark brown with pale stem.

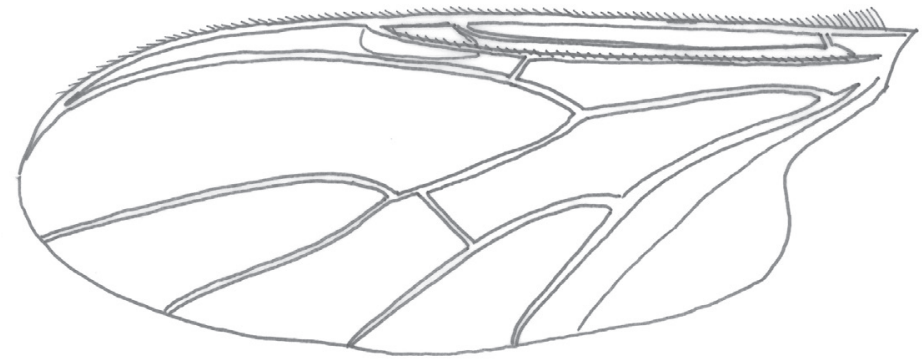

Figure 32. Dilophus sp., female, wing. Scale bar: $1 \mathrm{~mm}$. 


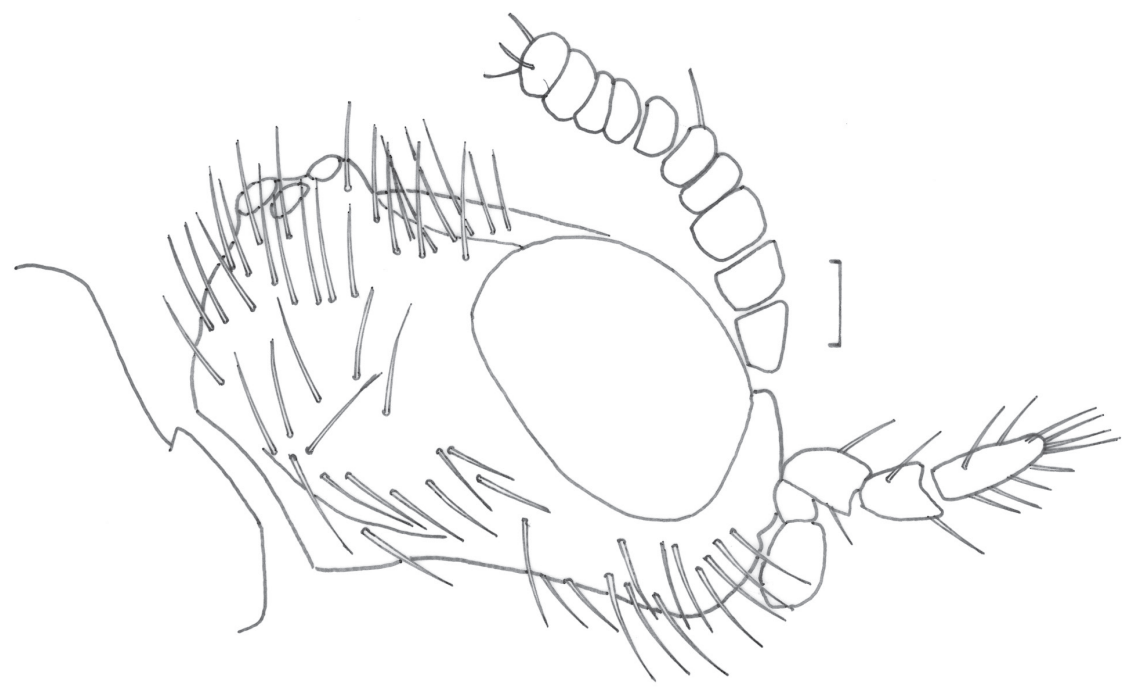

Figure 33. Dilophus sp., female, head. Scale bar: $0.1 \mathrm{~mm}$.

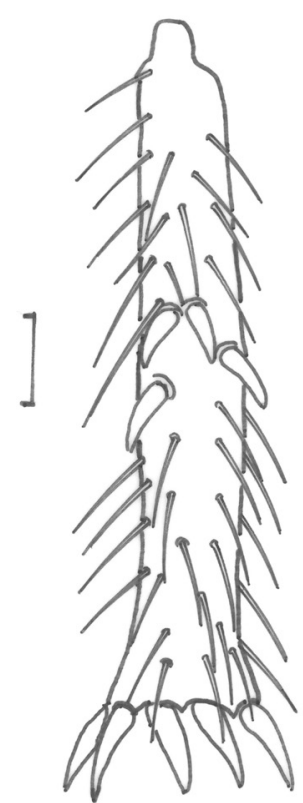

Figure 34. Dilophus sp., female, fore tibia. Scale bar: $0.1 \mathrm{~mm}$.

Legs: Black with medium-length, dark setae. Protibia (Fig. 34) with four sharp, semi-erect mesal spines, the two most basal ones close-set, the two more distal separated by about one spine length. Apical circlet with eight sharp spines. Mid and hind legs slender throughout. Fore femur $0.63-0.72 \mathrm{~mm}$ long, $0.23 \mathrm{~mm}$ wide $(\mathrm{N}=2)$, fore tibia $0.75 \mathrm{~mm}$ long, $0.10 \mathrm{~mm}$ wide $(\mathrm{N}=1)$. Mid femur $1.03 \mathrm{~mm}$ long $(\mathrm{N}=1)$. Hind femur $1.13-1.57 \mathrm{~mm}$ long $(\mathrm{N}=2), 0.17-0.18 \mathrm{~mm}$ wide $(\mathrm{N}=2)$, hind tibia $1.12-$ $1.60 \mathrm{~mm}$ long, $0.08-0.12 \mathrm{~mm}$ wide, hind first tarsomere 0.41-0.53 mm long, $0.05 \mathrm{~mm}$ wide.

Wing (Fig. 32): Rather crumbled in the newly acquired specimens. The specimen studied by Skartveit (2009) with wing as in Fig. 32, wing length $4.4 \mathrm{~mm}$. Almost hyaline, costa and R-veins dark brown, more posterior veins lighter brown but still distinctive. All veins are fine, no conspicuous thickenings. Costa with biseriate, rather dense, pale setulae, basally about as long as the width of the costal cell, decreasing in length apicad. Costa extends to about half-way between apices of $\mathrm{R}_{4+5}$ and $\mathrm{M}_{1}$. Pterostigma oval, brown, distinctive. Humeral vein present, subcosta fine, straight, running well separated from $R_{1}$ in entire length. Basal $R$ and $\mathrm{R}_{1}$ dorsally with uniserial, fine, dark setulae which are about as long as the width of the vein and separated by about as much as their length, veins otherwise bare. Radial sector about one-third the length of crossvein R-M. $\mathrm{R}_{4+5}$ gently curved. Area between $\mathrm{R}_{4+5}$ and $\mathrm{M}_{1}$ about 1.5 times as wide as fork of M. M-veins apically straight. Crossvein $\mathrm{M}-\mathrm{CuA}$ meets $\mathrm{M}$ well basad of furcation. $\mathrm{CuA}$ with rather long stem and short fork, $\mathrm{CuA}_{2}$ apically a little curved basad. CuP running approximately parallel to $\mathrm{CuA}$, rather indistinctive. $\mathrm{A}_{1}$ apparent on stem of wing only.

Abdomen: Strongly swollen in specimen at hand, membraneous areas stretched. This is presumably because it is egg-filled. Tergites and sternites clad with short, dark setae.

\section{Discussion}

Bibio succineus is the first Bibio species formally named from amber fossils. This is a bit peculiar since the genus is common to abundant in Tertiary compression fossils from Europe (e.g., Skartveit and Pika 2014; Skartveit and Nel 2017) and other bibionid genera are known from numerous amber specimens. It may have to do with habitat preferences. In the recent, European fauna, 32 species are known in the genus Bibio (Skartveit 2013), of these only four (Bibio clavipes, B. handlirschi, B. nigriventris and $B$. varipes) are normally found in closed forest habitats (Skartveit, personal observation). On the other hand, species of the genus Dilophus, which are not that rare in 
amber fossils, are also not commonly found in forests in the recent fauna. Most Bibio species are fairly large-sized (most are $>6 \mathrm{~mm}$ ), and amber fossil samples are strongly biased towards small-sized specimens, this may also be part of the explanation.

While there are many similarities between the faunas of Baltic and Rovno amber (e.g., Szwedo and Sontag 2013), there may also be some differences (Perkovsky et al. 2010). Bibionid flies are often widespread, and they also appear to be quite persistent in time (e.g., Wedmann and Skartveit 2020; Skartveit and Wedmann 2021), thus it is not surprising that a species described from Baltic amber also turns up in Rovno amber, even if this may have been deposited further south than Baltic amber (Mänd et al. 2018).

Although amber fossils may be excellently preserved with anatomical structures visible in great detail, in most specimens some traits are not visible because of opaque emulsions (Verlumung), because they are covered by other body parts or because they have been deformed (e.g., crumbled wings). For abundant taxa there may be a large number of specimens available to pick from, but for less abundant taxa such as Bibionidae the taxonomy may have to rely upon less-than-perfect specimens. When this is the case, finding new specimens of already described species offers an opportunity to gradually improve the knowledge of the taxon. This is so with all fossil materials, with the possible exception of limited outcrops which are no longer available for sampling, any fresh set of specimens found offers an opportunity to improve upon the taxonomy of any group, and any fossil classification should be viewed as preliminary, pending the discovery of new material.

Presently, a large fraction of the Baltic amber material available has been treated with an autoclave to improve the transparency and general appearance of the amber (Hoffeins 2012). Unfortunately, this may alter the appearance of the specimens in fairly unpredictable ways, and may destroy much taxonomically relevant information (Hoffeins 2012).

\section{Acknowledgements}

Christel and Hans-Werner Hoffeins, Hamburg kindly made material from their collection available for study, including the new specimens of Hesperinus electrus and Dilophus clavicornus. The female specimen of Bibio succineus was made available to me by Friedrich Kernegger, Hamburg. The other specimens here described were acquired through the internet stores http://www. ambertreasure4u.com and https://www.amberinclusions. eu/. Digital images were kindly provided by Christel and Hans-Werner Hoffeins (Figs 1, 3, 9), Marius Veta (Figs 2, 4, 5, 8) and Jonas Damzen (Figs 6, 7, 11). Thanks are also due to Frank Menzel, SDEI, Müncheberg for facilitating the museum deposit of the type material. Two referees provided useful and constructive criticism on the first submission of this paper.

\section{References}

Cockerell TDA (1917) New Tertiary insects. Proceedings of the United States National Museum 52: 373-384. https://doi.org/10.5479/ si.00963801.52-2181.373

Cockerell TDA (1921) Fossil arthropods in the British Museum -VI. Oligocene insects from Gurnet Bay, Isle of Wight. Annals and Magazine of Natural History 9: 453-480. https://doi. org/10.1080/00222932108632550

Collomb F-M, Nel A, Fleck G,Waller A (2008) March flies and European Cenozoic palaeoclimates (Diptera: Bibionidae). Annales de sociéte entomologique de France (nouvelle serie) 44: 161-179. https:// doi.org/10.1080/00379271.2008.10697553

Dlussky GM, Rasnitsyn AP (2009) Ants (Insecta: Vespida: Formicidae) in the Upper Eocene Amber of Central and Eastern Europe. Paleontological Journal 43: 1024-1042. https://doi.org/10.1134/ S0031030109090056

Gee J, Nel A, Menier J-J, de Ploëg G (2001) A new lovebug fly (Insecta, Diptera) from the lowermost Eocene amber of the Paris Basin. Geodiversitas 23: 341-348. http://sciencepress.mnhn.fr/en/periodiques/ geodiversitas/23/3/une-nouvelle-espece-de-bibionidae-insecta-diptera-de-1-ambre-eocene-inferieur-du-bassin-parisien

Hardy DE (1971) A new Plecia (Diptera, Bibionidae) from Mexican amber. University of California, Publications in Entomology 63: 65-67. https://www.phylonimbus.com/references/article/26659/a-new-plecia-diptera-bibionidae-from-mexican-amber/

Hoffeins C (2012) On Baltic amber inclusions treated in an autoclave. Polskie Pismo Entomologiczne 81: 165-181. https://doi. org/10.2478/v10200-012-0005-z

Krivosheina NP (1997) Family Hesperinidae. In: Papp L, Darvas B (Eds) Contributions to a Manual of Palaearctic Diptera (Vol. 2), Nematocera and Lower Brachycera. Science Herald, Budapest, 35-39.

Krzeminski W, Blagoderov V, Azar D, Lukashevich E, Szadziewski R, Wedmann S, Nel A, Collomb F-M, Waller A, Nicholson DB (2019) True flies (Insecta: Diptera) from the late Eocene insect limestone (Bembridge Marls) of Isle of Wight, England. Earth and Environmental Science Transactions of The Royal Society of Edinburgh. 1-60. https://www.cambridge.org/core/journals/earth-and-environmental-science-transactions-of-royal-society-of-edinburgh/article/ true-flies-insecta-diptera-from-the-late-eocene-insect-limestonebembridge-marls-of-the-isle-of-wight-england-uk/CB07CDF0AD64CEE43AA145211EB15EE4

Mänd K, Muehlenbachs K, McKellar RC, Wolfe AP, Konhauser KO (2018) Distinct origins for Rovno and Baltic ambers: Evidence from carbon and hydrogen stable isotopes. Palaeogeography, Palaeoclimatology, Palaeoecology 505: 265-273. https://doi.org/10.1016/j.palaeo.2018.06.004

Merz B, Haenni J-P (2000) Morphology and terminology of adult Diptera (other than terminalia). In: Papp L, Darvas B (Eds) Contributions to a Manual of Palaearctic Diptera (Vol. 1), General and Applied Dipterology. Science Herald, Budapest, 21-51.

Perkovsky EE, Makarkin VN (2019) A new species of Succinoraphidia Aspöck \& Aspöck, 2004 (Raphidioptera: Raphidiidae) from the late Eocene Rovno amber, with venation characteristics of the genus. Zootaxa 4576: 570-580. https://doi.org/10.11646/zootaxa.4576.3.9

Perkovsky EE, Rasnitsyn AP, Vlaskin AP, Taraschuk MV (2007) A comparative analysis of the Baltic and Rovno amber arthropod faunas: representative samples. African Invertebrates 48: 229-245. https:// journals.co.za/content/nmsa_ai/48/1/EJC84578 
Perkovsky EE, Zosimovich VYu, Vlaskin AP (2010) Rovno amber. In: Penney D (Ed.) Biodiversity of Fossils in Amber from the Major World Deposits. Siri Scientific Press, Manchester, 116-136. https://www.worldcat.org/title/biodiversity-of-fossils-in-amber-from-the-major-world-deposits/oclc/671260626

Peterson BV (1975) A new Cretaceous bibionid from Canadian amber (Diptera, Bibionidae). The Canadian Entomologist 107: 711-715. https://doi.org/10.4039/Ent107711-7

Ševčik J, Kaspřák D, Mantič M, Fitzgerald S, Ševčiková T, Tóthová A, Jaschhof M (2016) Molecular phylogeny of the megadiverse insect infraorder Bibionomorpha sensu lato (Diptera). PeerJ4: e2563. https://doi.org/10.7717/peerj.2563

Skartveit J (2009) Fossil Hesperinidae and Bibionidae (Diptera: Bibionoidea) from Baltic amber. Studia Dipterologica 15: 3-42. https:// www.semanticscholar.org/paper/Fossil-Hesperinidae-and-Bibionidae-from-Baltic-und-Skartveit/8a66c7b3395105af96038cffb$34 \mathrm{~b} 8927486 \mathrm{a} 7 \mathrm{c} 60$

Skartveit J (2013) Fauna Europaea: Bibionidae. In: de Jong H (Ed.) Fauna Europaea: Diptera. Fauna Europaea version 2017.06. https:// fauna-eu.org

Skartveit J, Ansorge J (2020) A new genus and subfamily of fossil Bibionidae (Diptera) from the Lower Cretaceous, with new classification of the Bibionidae. Palaeoentomology 3/2: 163-172. https://doi. org/10.11646/palaeoentomology.3.2.5

Skartveit J, Bechly G (2013) Occurrence of Plecia pristina Hardy, 1971 (Diptera, Bibionidae) in Dominican amber. Neues Jahrbuch für Geologie und Paläontologie 269/1: 97-100. https://doi. org/10.1127/0077-7749/2013/0338
Skartveit J, Nel A (2017) Revision of Bibionidae (Diptera) from French Oligocene deposits. Zootaxa 4225: 1-83. https://doi.org/10.11646/ zootaxa.4225.1.1

Skartveit J, Pika M (2014) Revision of Bibionidae described by Oswald Heer from the Miocene of Öhningen, Southern Germany. Mitteilungen der schweizerischen entomologischen Gesellschaft 87: 103-134. https:// www.semanticscholar.org/paper/Revision-of-Bibionide-(Diptera)named-by-Oswald-the-Skartveit-Pika/c7803c54a0408417074499adb289800f494e6cc9

Skartveit J, Wedmann S (2016) Fossil Bibionidae (Insecta: Diptera) from the Eocene of Grube Messel, Germany. Studia Dipterologica 22: 77-83. http://www.studia-dipt.de/data/22077.pdf

Skartveit J, Wedmann S (2021) Revision of fossil Bibionidae (Insecta: Diptera) from the Oligocene of Germany. Zootaxa 4909: 1-77. https://doi.org/10.11646/zootaxa.4909.1.1

Szwedo J, Sontag E (2013) The flies (Diptera) say that amber from the Gulf of Gdańsk, Bitterfeld and Rovno is the same Baltic amber. Polskie Pismo Entomologiczne 82: 379-388. https://doi.org/10.2478/ pjen-2013-0001

Waller A, Nel A, Menier J-J (2000) Le premier Dilophus fossile de l'ambre dominicain (Diptera, Bibionidae). Revue française d'Entomologie (N.S.) 22: 149-153. https://www.semanticscholar.org/ paper/Le-premier-Dilophus-fossile-de-1\%27ambre-dominicainWaller-Nel/7e4aa01c5e1452d6e4750febda94d9e6e1f7478b

Wedmann S, Skartveit J (2020) First march flies (Insecta: Bibionidae) from the Miocene Gracaniča mine. Palaeobiodiversity and Palaeoenvironments 100: 585-591. https://doi.org/10.1007/s12549-01800369-w 